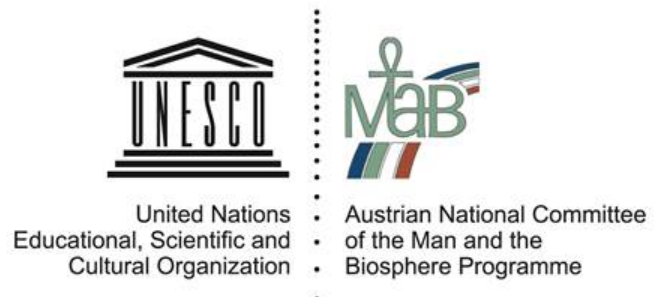

\title{
Samothraki as a Biosphere Reserve (SamoMAB):
}

\section{Securing continuity of science-civil society collaboration in a systemic design}

\author{
Univ.-Prof. Dr. Marina Fischer-Kowalski ${ }^{1}$ \\ Dr. Panos Petridis ${ }^{1}$ \\ Mag. Dominik Noll ${ }^{1}$ \\ Dr. Nikos Skoulikidis ${ }^{2}$ \\ MSc. Anastasia Lampou ${ }^{2}$ \\ Dr. George Katopodis ${ }^{2}$
}

${ }^{1}$ Institute of Social Ecology, University of Natural Resources and Life Sciences (BOKU), Schottenfeldgasse 29, A-1070 Vienna, Austria

${ }^{2}$ Hellenic Cetner for Marine Research (HCMR), 46, 7 km Athens Sounio ave., P.O. Box 712, P.C. 19013 Anavyssos, Attiki Greece

Correspondingemail:dominik.noll@boku.ac.at

ISBN-Online: 978-3-7001-8498-0

DOI: $10.1553 /$ SamoMAB
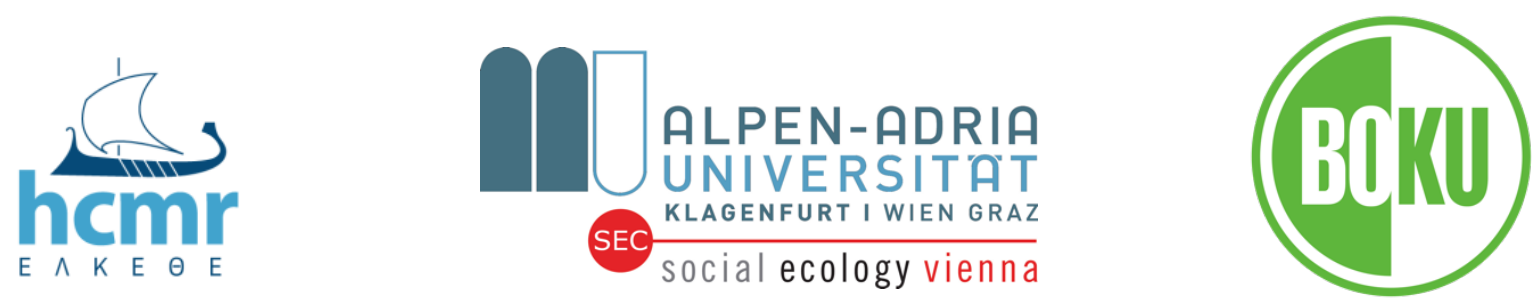


\section{Contents}

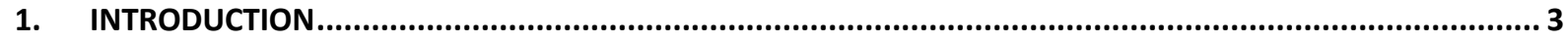

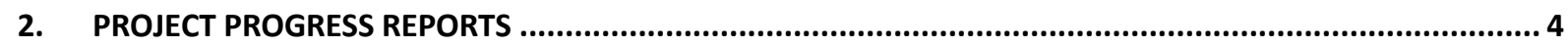

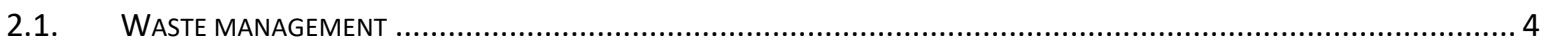

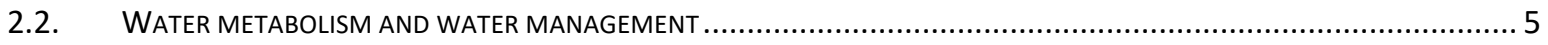

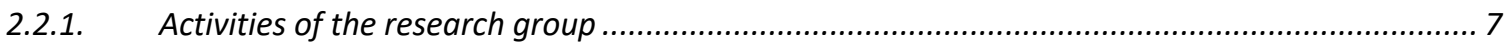

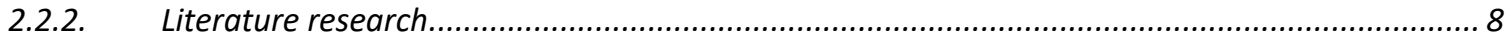

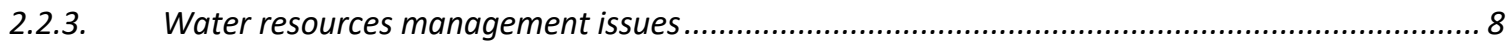

2.2.4. Registration and mapping of municipal and private water abstraction points ........................... 9

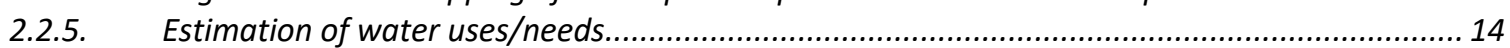

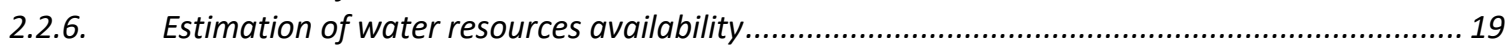

2.2.7. Estimation of water resources quality .................................................................................. 25

2.2.8. Preliminary water resources management plan .................................................................... 29

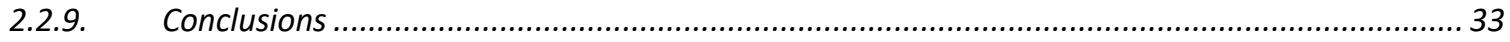

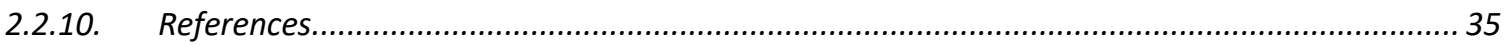

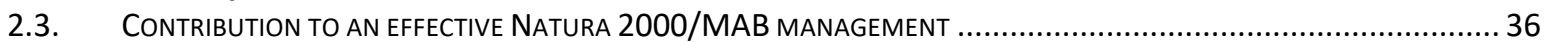

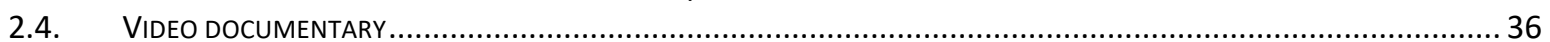

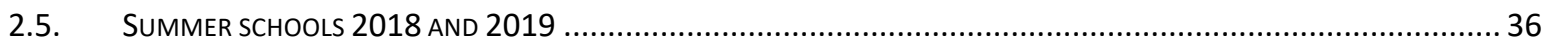

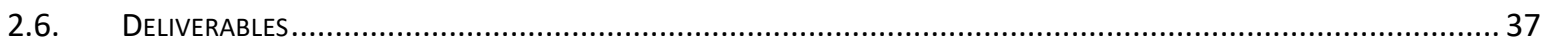

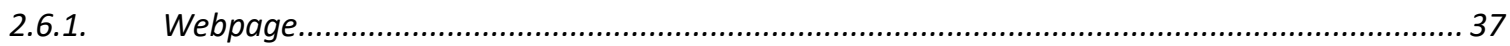

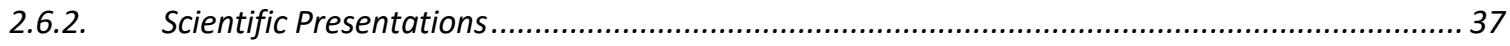

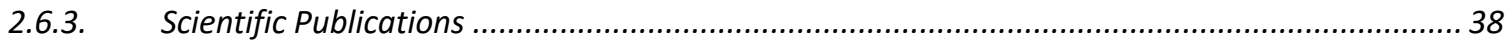

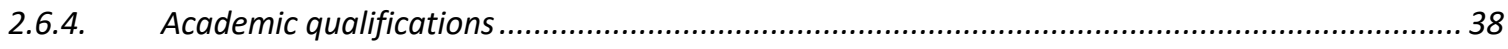

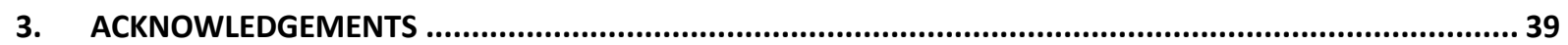

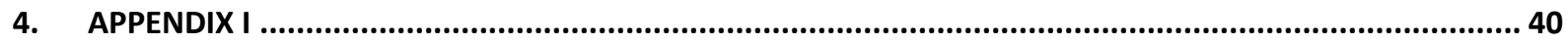

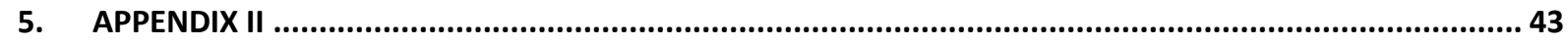

6. APPENDIX III 


\section{Introduction}

The current project builds upon the achievements of a long and successful research process initiated by the Austrian MAB committee and realized by the Vienna Institute of Social Ecology (SEC), for creating a new Biosphere Reserve (BR) on the Greek island of Samothraki. Two feasibility studies, financed by seed funding from the Austrian MAB committee, and one in collaboration with UNESCO Venice ${ }^{1}$ have been instrumental in this respect in setting the ground and mobilizing local support that has resulted in two applications to UNESCO for Samothraki to be included in the World Network of Biosphere Reserves (2011 and 2013), that were unanimously supported by the Mayor and the Municipal Council, and found support from the local community (Fischer-Kowalski et al. 2011, Petridis 2016). One further key outcome of this preparatory work and communication efforts was the legal establishment of a local association "Sustainable Samothraki" for assuming a role in the future BR management and promoting local sustainability initiatives. Our activities over the past years have been highly acknowledged, including the Sustainability Award 2010 received by the Austrian Ministry of Science and Research, and the Honorary Citizenship Marina Fischer-Kowalski received from the Municipality of Samothraki in 2012 for her long standing and sustained efforts to transform the island into a MAB Reserve. Moreover, the previous projects have led to the development of an ongoing intellectually challenging research program ${ }^{2}$ that aims at supporting the local administration in achieving practical sustainable development goals (Petridis \& Fischer Kowalski 2016, Petridis et al. 2017).

The project SamoMAB successfully enabled the continuation of the research process on the island. The current project has been becoming instrumental in capitalizing on the emergent momentum, preserve the current achievements and support the local administration in finding and applying sustainable solutions in two key priority areas: waste and water management, as well as a functioning conservation management. Thus, the present project plays an important role in an ongoing process that has been initiated by the Austrian MAB committee. The overall aims of the project have largely been achieved:

1. Elaboration of some key modules towards sustainable development for Samothraki Biosphere Reserve candidate, in particular relating to priority action areas as identified by the Municipality and researchers, namely waste management, water management, and efficient nature conservation within the Natura 20000 network, leading to first steps in implementation in collaboration with a research consortium, the local administration, and civil society networks.

2. Samothraki was included into the international LTER (Long Term Ecological Research) network. The integration of social science and practices in order for Samothraki to become part of the LTSER (Long Term Socio Ecological Research) is under way.

3. Contribution to the development of a sound joint management plan of the Natura 2000/MAB, sensitizing residents about the relevance and importance of nature conservation areas, as well as their economic importance in local development.

4. Reinforcement of the regional Mediterranean insular network of Biosphere Reserves, by contributing insights in terms of (structural and procedural) management guidelines and monitoring tools for sustainable development along the lines of the Sevilla Strategy and the Madrid Action Plan, but also providing dissemination material for wide circulation within the MAB network, thus contributing to the traditionally less developed logistics function of Biosphere Reserves.

\footnotetext{
${ }^{1}$ Austrian Academy of Sciences (ÖAW) financed projects: "Feasibility study for creating a new MABpark on the island of Samothraki, Greece" and "Outlining a sustainable future for the island of Samothraki (Greece) as a Biosphere Reserve and creating a regional showcase (Phases I \& II)".

${ }^{2}$ Austrian National Science Fund (FWF) financed projects: SUSAKI (P27951-G7): "Socioecological transitions, sustainability and collapse of island communities", and CiSciSusaki (F15TCS00022): "Citizen Science as a key pathway to achieve effective nature conservation and a sustainability transition on the island of Samothraki". Information on all past and ongoing research activities can be found at the project website: http://sustainable-samothraki.net/.
} 


\section{Project progress reports}

The project had planned the following activities for the period September 2017 - December 2019, all of which have been achieved.

\subsection{Waste management}

Due to Samothraki's mountainous morphology (most of it included in the EU Natura 2000 network), the numerous water streams and the plethora of archaeological sites, it is not possible to establish a landfill site on the island that would comply with national environmental and cultural regulations and would also have sufficient distance from settlements and waterways. Until recently, there was effectively no waste management plan on the island, with all waste being collected and either deposited on open dumps or incinerated without control, posing a risk to both human health and the environment. We have now reached a point that the approximately $1.100 \mathrm{t}$ of annually generated waste, including $8 \%$ recyclable waste, is no longer dumped, but is shipped to landfills and recycling facilities on the mainland at high cost ( $€$ 200.-/ton). The issue of waste management in Samothraki, therefore, remains pressing and is especially relevant to the tourist season at which time infrastructural facilities are lagging much behind growing demand. The municipality has recently developed a waste management plan (Municipality of Samothraki 2015) but encounters many difficulties in enacting this plan. Treating waste on site as much as possible would relieve the budget of the municipality. In collaboration with local initiatives, we have made it one of our key priorities to support the Mayor in his efforts to pursue the waste management plan and save money currently paid for waste deposition on the mainland. Following activities were carried out:

- It is strategically most important to separate the organic waste fraction and deal with it on the island. Efforts to motivate individual households to compost their organic wastes have not been successful and do not look very promising on a larger scale. In reference to real life laboratories (Gaia 1, 2018. Special Issue) we started a compost experiment with schoolchildren on the island. In collaboration with the Sustainable Samothraki Association and RE:THINK from Kalamata, three large wooden composters were installed at the primary schools of Kamariotissa and Lakkoma and at the youth center in Chora. 180 compost containers were distributed among schoolchildren. Children were encouraged to bring organic waste from home to the school by these containers, in order to harvest fertile soil later. Educators, pupils and parents were informed about composting and the correct usage of the RE:THINK composting bins. The project is complemented with educational games and activities, designed by the Sustainable Samothraki team. Separate collection of organic waste has to be publicly understood, learned and well organized. It will take several years until this works well, and requires substantial outreach communication, monitoring and feedback. The current project marks a beginning towards this goal.

- Following the preliminary study about the waste management system of the island (Noll et al. 2016), a study about the expansion of the built environment was conducted and published in the Journal of Resources, Conservation and Recycling (Noll et al. 2019). This study serves as a first approach towards quantifying the amount of construction and demolition waste that was and is generated and dumped mostly uncontrolled and often illegally somewhere on the island. During the preparation phase of the publication, a municipal meeting was held in spring 2018, in order to inform the vice mayors and the administration on the results of the study, problems to be expected in the future, and possible strategies for waste reduction.

- Waste flows were further analyzed by a team of students during the summer school 2019 (working paper in preparation). Two students are interested in conducting a Master's Thesis about waste management on small islands and are supervised by the project team. 


\subsection{Water metabolism and water management}

Samothraki is rich in surface waters. Numerous small mountainous springs, fed by snowmelt and precipitation, are developed within deep ravines, creating numerous streams (perennial and temporary) with substantial flow considering the dimension of the island. Nevertheless, there are some places (settlements and crop fields) with scarcity in water due to the lack of appropriate and sustainable water management. Water supply is organized via communal cisterns on the one hand, a partly archaic distribution system and ancient neighborhood rights on the other. At present, 35 springs and 25 wells are used for drinking water supply. Irrigation water management is carried out in traditional, oldfashioned ways that are currently often inadequate to satisfy the needs of all farmers. Historically, there is also a lack of dialogue and trust between the local administration and stakeholders. River water resources mismanagement has also negative ecological consequences. Platia and Xiropotamos streams are examples of human inability to balance the needs with the available natural resources; there is evidence that water abstractions from these rivers result in artificial periodic desiccation of the streams' lower reaches thus threatening ecological quality. Furthermore, a lack in domestic wastewater treatment in combination with the existence of sewage systems impacts the physico-chemical and biological quality of two streams, i.e. Katsambas and Lakoma (Skoulikidis et al. 2014; Skoulikidis 2016; Eidinger et al. 2016). In addition, the first River Basin Management Plan of Eastern Macedonia \& Thrace (2012) cannot serve as basis for water resources management, since it does not identify any relevant issues or measures specifically for the island Samothraki, apart for the need of monitoring groundwater body quality characteristics. Preliminary studies in the context of "Samothraki Nature Observatory" and the Summer School 2016, have shown that data on the available water resources are either missing or are inadequate. In order to cover these gaps, targeted related research has been started within SamoMAB:

Researchers from the Hellenic Centre of Marina Research (HCMR) who had been long-standing partners on our Samothraki research, were subcontracted for the following activities: In phase I they conducted an extensive preparatory literature review and a field trip to Samothraki in September 2018. We used this fieldtrip to conduct meetings with personnel from the Municipalitiy's Technical Service and the Mayor to collect information on the organizational structure of the water management on the island and Municipal water abstraction points in order to calculate water demand. Field measurements were taken in order to estimate and correct coordinates of water abstraction points. They further measured the discharge of springs for domestic water supply. Phase II continued with recording and correction of the measurements of abstraction points and estimated water discharge. They further conducted hydrogeological research for ground water measurements. 


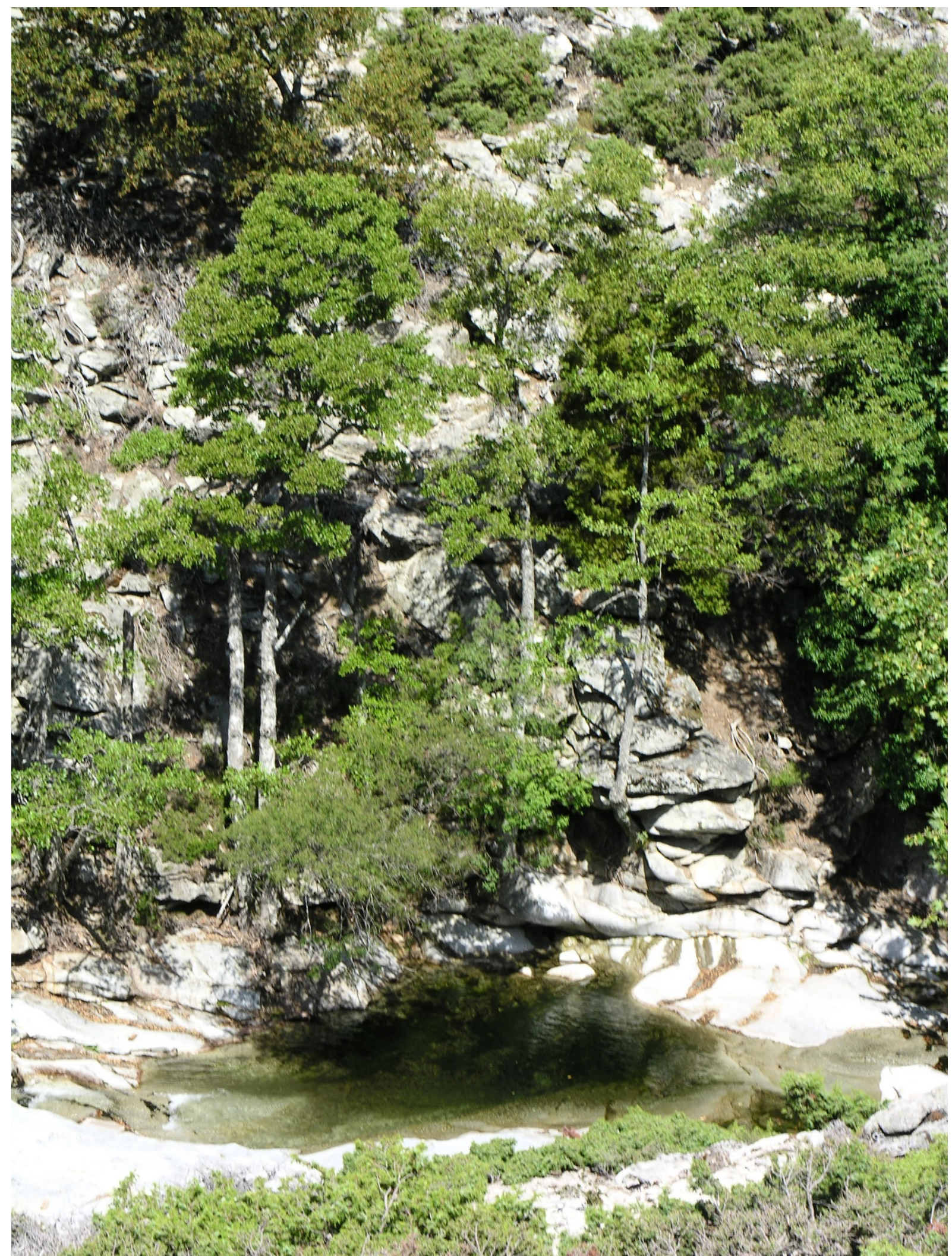

The Fonias stream headwaters (photo by N. Skoulikidis) 


\subsubsection{Activities of the research group}

During the initial phase of the project, we carried out an extended literature research to collect studies related to the water resources of the island. Furthermore, in order to collect information regarding water abstraction and water uses covered by the Municipality of Samothraki, we visited the Island in the third week of September 2018 up to the end of the month. During that time, we had several meetings with the personnel of the Municipality's Technical Service Department and the Mayor, we collected relevant information and we implemented field work activities. It should be mentioned that a major problem for implementing this study was connected with the collection of water resources management information and data; a related data base is missing, the data are only partly digitized, and the main information is scattered in paper or orally among different members of the staff of the Municipality's Technical Service.

It should be underlined that, despite the contract commitment, which is limited on municipal data, efforts were placed on gathering data also from private water users.

Thus, during the first phase of the project, we: (i) collected information on the organizational structure of the Municipality of Samothraki regarding water resources management, (ii) collected information and data on municipal water abstraction points (springs and drillings) for domestic purposes, data on water used for irrigation from both municipal and private drillings or wells, as well as data on livestock and crop type and area, in order to calculate respective water needs, (iii) performed field measurements in order to estimate or correct the coordinates of all water abstraction points, and (iv) measured, where possible, the discharge of springs used by the Municipality for domestic water supply.

At that time, head of the Technical Services Department was Parthena Romanidou who greatly assisted the data collection and field working activities.

In the second phase of the project we: (i) continued the recording and correction of the coordinates of all water abstraction points used for domestic and irrigation needs, (ii) performed field measurements to estimate stream water discharge, and (iii) carried out a hydrogeological research to estimate the characteristics and quantities of ground waters.

As the island faces water shortages during summer, estimations on water availability and use and water management plans should particularly focus on the dry period of the year ${ }^{3}$. We thus decided to carry out field work activities during the dry season of the year since at that time freshwater resources reach annual minima; the timing of field working was ideal for the purposes of the study, since 2018 and 2019 were dry hydrological years with restricted snow fall. In fact, the annual rainfall for 2018 was $590.4 \mathrm{~mm}$ and for 2019 around $515 \mathrm{~mm}$ were substantially lower than the multiyear (2008-2017) average (706.4 mm) (Fig. 1).

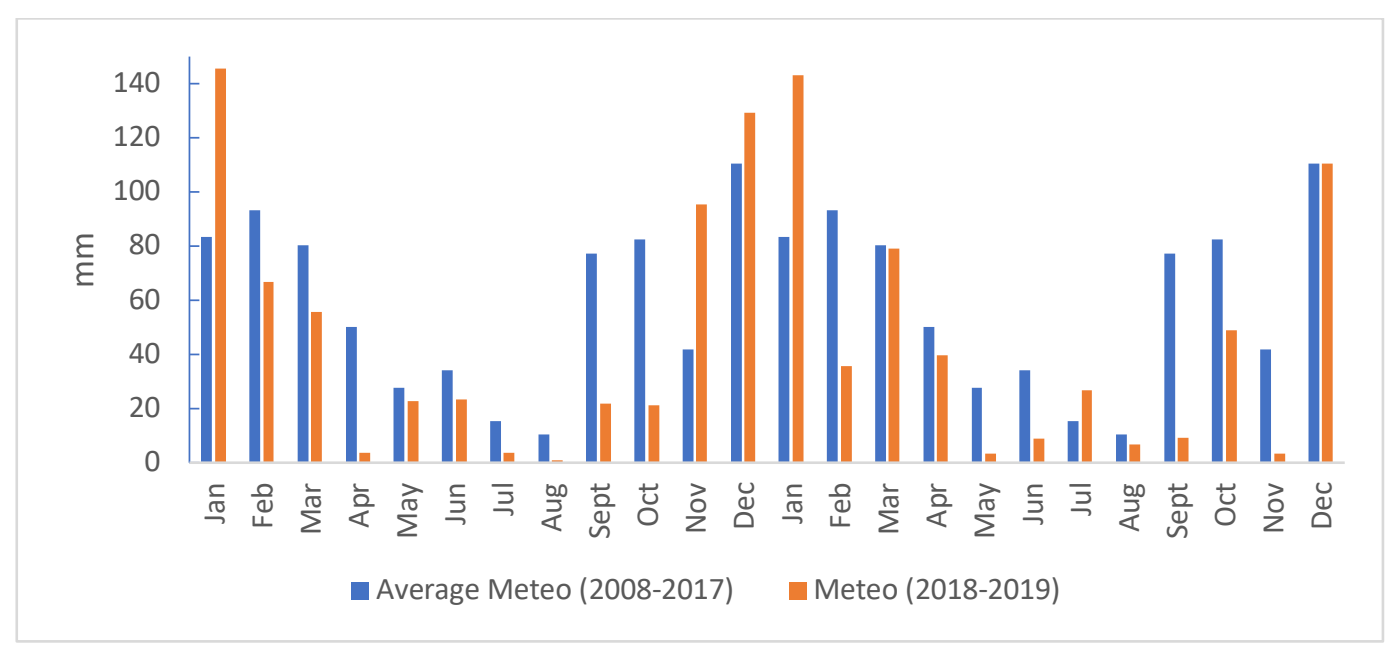

Figure 1. Comparison between monthly precipitation of 2018 and 2019 and the mean annual one (2008-2017) at the Samothraki meteorological station located in Chora.

${ }^{3}$ The management plan additionally focuses on floods. 


\subsubsection{Literature research}

A number of studies have been carried out on the island by the Institute of Geological and Mineral Exploration (IGME). In particular, in the framework of the IGME's project "Special hydrologic and hydrogeological research -Collection of long-term data", a hydrogeological research study has been carried out (Vergis 1984), in which hydrological data of 5 drillings and 40 springs have been reported for the dry and the wet periods of 1980. Data collection continued in the periods 1981-1990 on the same drillings and on a restricted number of springs (Vergis 1984, 1986, 1993; Tsanaktzis 1990; Romaidis et al. 2008, 2010). In addition, Romaidis (2006) conducted a hydrogeological study focusing on six springs. To obtain these studies was not that easy as one would expect.

\subsubsection{Water resources management issues}

Since 2011, the Municipality of Samothraki has, according to the law, a detailed internal organizational structure. According to this, the Municipality is responsible for carrying out water resources management. However, in the practice, citizens may independently cover their needs for households, touristic activities, or irrigation purposes.

\section{Related structure of Samothraki municipality}

According to Decision 15240 (Government Gazette ${ }^{4}$ Nr. 2279, 12.10.2011), the Municipality of Samothraki has an Internal Organizational Structure that includes a number of collaborating operational units. Here we describe units 2 and 6 which include activities relevant to the purposes of our study.

The Operational Services Unit (Unit 2), with the Independent Office for Programming, Informatics and Transparency, is actually the planning unit, supporting the Municipality regarding the outcomes of the 5-year Operational Programs and the Annual Action Programs. The responsibilities of this office include (among others) a) the collection, processing, documentation and updating of geographic, demographic, economic and social data, b) research and implementation of studies related to the development needs of the Municipality, c) investigation of the feasibility of developmental proposals and prioritization of projects, actions and measures, d) study and design of economic development programs through the exploitation of local natural resources, development of human resources, exploitation of municipal property, as well as creation and management of local economic infrastructures, and e) the integration of municipal plans and actions in developmental programs and monitors their implementation.

The Supporting Services Unit (Unit 6), which actually implements the planning objectives. It includes, among other departments, the Independent Department of Technical Services and Quality of Life. This Department is responsible for the execution and maintenance of all kinds of municipal technical works, the protection and upgrading of the natural, architectural and cultural environment, the collection and transport of waste, the separate collection and transport of recycled materials, etc. The Department includes the following Offices:

- Technical Works Office

- Office of Electromechanical Works and Transportation

- Water-Sewerage Office

- Office of the Environment, Cleanliness, Green Areas and Civil Protection

The Technical Works Office collaborates with Unit 2 in planning the Municipality's action programs and the implementation of technical projects, including hydraulic and land reclamation projects and checks related studies (preparation with the Office's staff or delegation to third parties).

The Water-Sewerage Office is responsible for planning expansion or renewal works for the water supply and sewerage networks, as well as for the repair, maintenance and good operation of drillings, water supply distribution systems, and water reservoirs, it controls the hydrometer records, etc.

Finally, the Office of Environment, Cleanliness, Green Areas and Civil Protection plans and proposes the implementation of policies, programs, actions and measures for protecting and upgrading the environment, ensures the protection and management of water resources and mitigates pollution,

${ }^{4}$ The official journal of the Government of Greece which lists all laws passed by Cabinet and President. 
monitors the implementation of protected areas in cooperation with other authorities, ensures the establishment and proper operation of waste collection and management. It recommends the regulation of environmental protection issues, according to the jurisdictions of the Municipality, e.g. for the establishment and operation of slaughterhouses, regarding environmental remediation issues, for the establishment of industrial and business areas and related environmental impact assessment studies (referred in Article 5 Law 2545/1997, Government Gazette 254, A), for following up programs for the Environment, Energy and Climate Change. It finally studies, plans and monitors the implementation of alternatives solid waste management systems (recycling).

Despite the high responsibilities of the Department of Technical Services and Quality of Life, the number of the staff currently working is only14, of which only four are highly educated, three are technicians and the rest workers. The head of the Department is a civil engineer (Paschalia Pavlidou), one is architect (Parthena Romanidou), one is agronomist (Doukas Chailas), one is environmentalist (Panayiota Fotaki), two are hydraulic technicians (Yiannis Koletsas and Nikos Koutsouris) who are mainly focusing on water resources management, and one electrician (Panayiotis Maltezos) who is responsible for groundwater management issues.

\subsubsection{Registration and mapping of municipal and private water abstraction points}

\section{Historical and current water use}

Water collection for domestic use in Samothraki can be traced back to the ancient times. In the area of the Sanctuary of the "Grate Gods" the Nike-fountain was found to the south of the ancient theatre. This was actually a water reservoir which was provided from springs of abundant supply. Excavations revealed a water supply network made out of clay material and an aqueduct with a pipe, both dated back to the Early Hellenistic period (323 - 220 B.C.). On the hill where the medieval fort of Gateluggi emerges, a rectangular aqueduct with a coating for sealing has been also excavated. Finally, an aqueduct with a dome form from the Roman times has been also discovered.

Nowadays, domestic water supply is carried out by surface and ground water abstraction by exploiting springs and wells/drillings, respectively. The increased use of surface water sources and the utilization of ground water sources in modern times is the result of the increase in population (especially in the touristic period), an increase of water use per capita regarding domestic use, and mainly due to high irrigation.

\section{Water abstraction points}

Regarding domestic use, the Municipality exploits a total of 18 springs, one well, and two drillings. In certain cases, when water shortage incidents occur during the summer period, spring water may be mixed with stream water, as in the case of the Varades water abstraction point. Apart from domestic use, water from these sources serves the needs of 13 hotels. Tables 1 and 2 provide the names of Municipal springs and drillings for domestic water use, their coordinates and the settlements that they serve.

Regarding irrigation, the Municipality manages 16 groundwater drillings, of which two are nowadays inactive (Table 3). Since 2015, the Municipality applies a system with electronic hydrometers, where each farmer uses a card to activate water abstraction from the drillings. The time of water consumption is registered on the card. According to the former mayor Athanasios Vitsas, this system substantially reduced water use from the drillings, as users pay 2.6 Euro per hour. Unfortunately, the disastrous flood of September 2017 destroyed all respective files and thus data on groundwater abstraction are not available for the years 2015-2017.

A problem with the registration of the necessary information, is connected with terminology; regarding the water abstraction points, there are differences between the codes used by the Municipality and those existing in the studies of IGME. Moreover, the IGME's codes differ between older and more recent studies. There were also problems regarding the coordinates and the names of the Municipal springs and boreholes. Missing or wrong coordinates and data of water abstraction points exacerbated our efforts. In the frame of this activity, we attempted to cover these gaps in close cooperation with Parthena Romanidou. In fact, we compiled existing data and information, and, regarding the Municipality data, we measured and registered missing coordinates of springs and drillings (Figure 2), corrected wrong 
ones and produced respective GIS maps. However, corrections of the IGME abstraction points was not possible.

A problem with monitoring municipal spring discharges of springs used for domestic water supply is that the exploitation of most of them is facilitated by means of cisterns constructed directly at the spring outflow connected with closed distribution pipes (Figure 3). As a result, in most of the cases it was not possible to measure discharge at the springs' outflow.

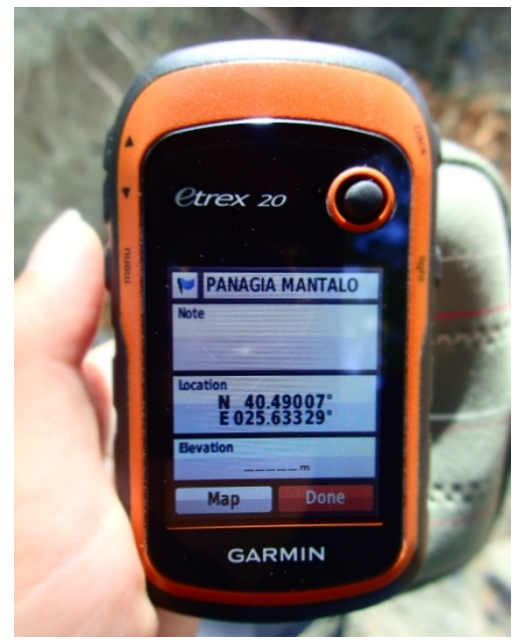

Figure 2. GPS measurements

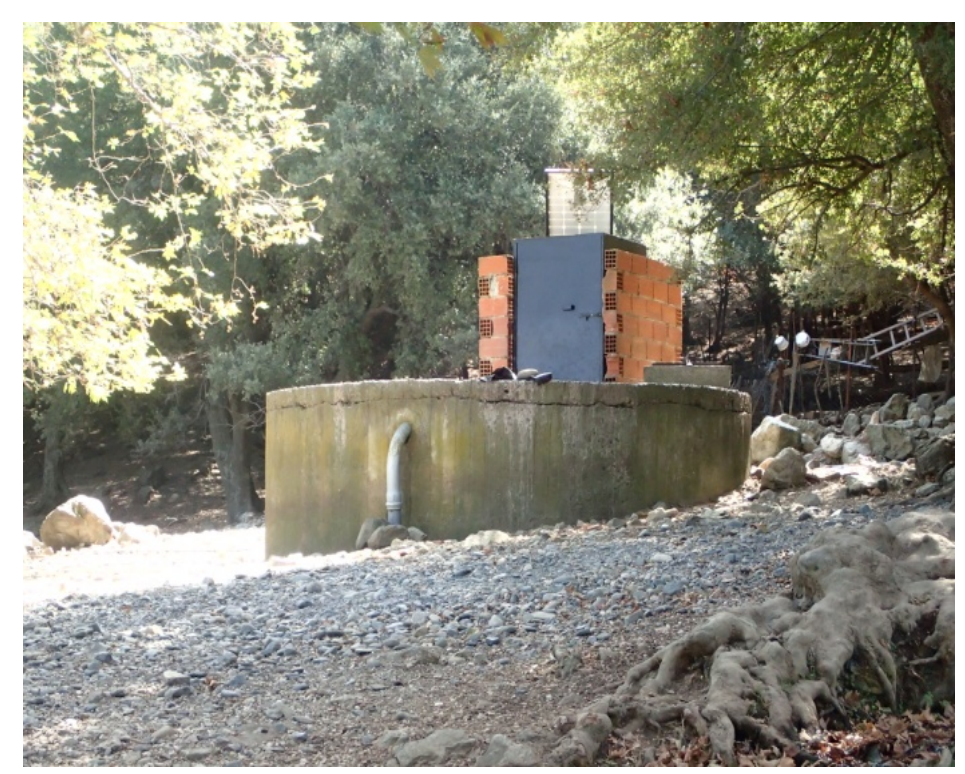

Figure 3. Cistern installed directly at a spring outflow

Regarding domestic use, the Municipality exploits a total of 18 springs, one well, and two drillings (Figure 4). Apart from domestic use, water from these sources serves the needs of 13 hotels.

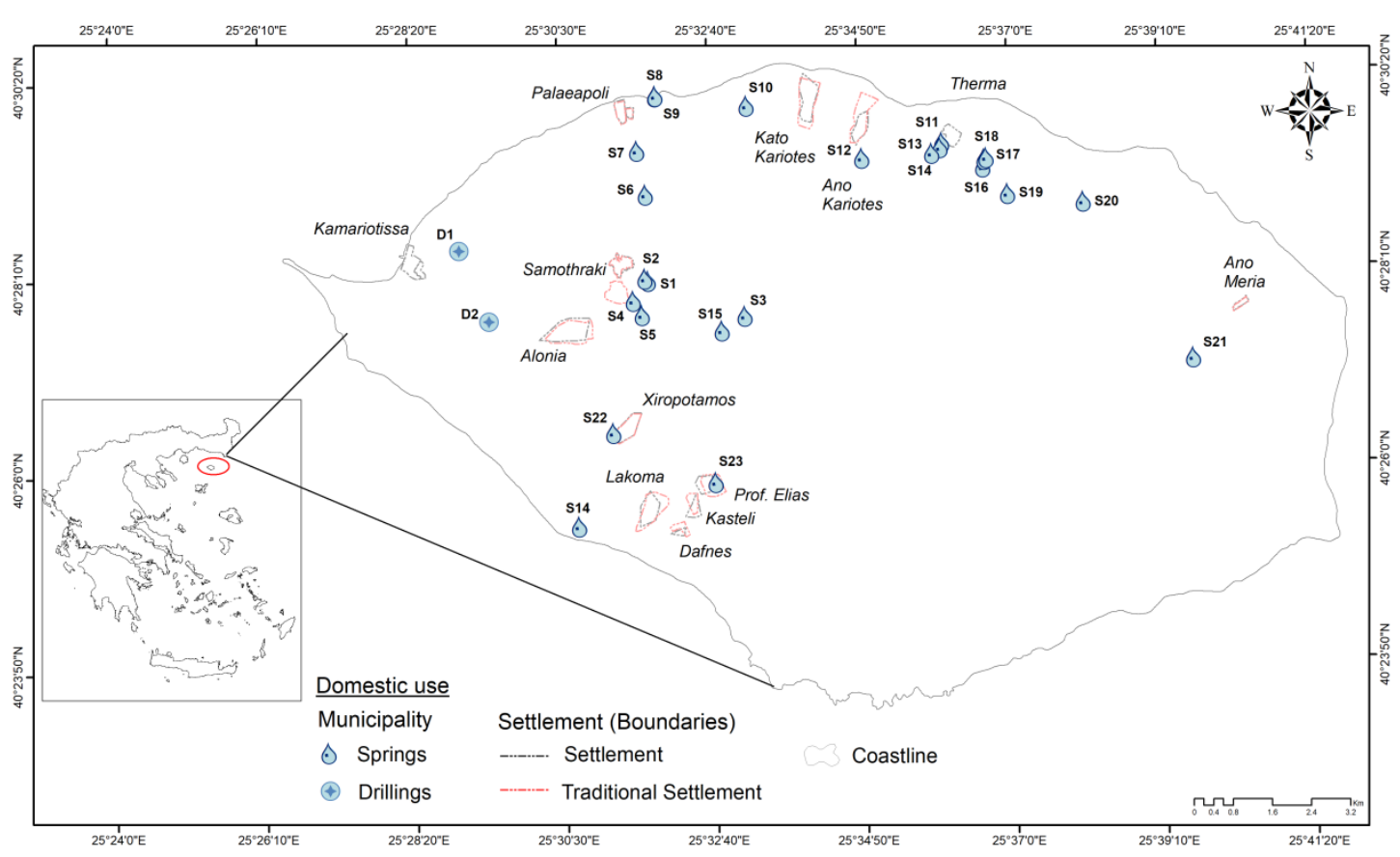

Figure 4. The springs and drillings that are exploited by the Municipality for domestic use.

To gain an overview regarding domestic water supply, details on the origin of water and the water supply system are given: 
Kamariotissa and Paleapoli are supplied by two springs located at Kopsi and by a third one within the archaeological site. These springs supply a $100 \mathrm{~m}^{3}$ reservoir, situated south of Paleapoli. Since the spring of the archaeological site has a lower altitude in respect to the reservoir, a pumping station with two pipes drives the water to Paleapoli and a third on to the Kamariotissa reservoir (200 m3). A new pipeline drives water from the Kamariotissa reservoir to Katsabas area to supply off-site areas. A drilling located east of Kamariotisa serves the increased needs of this settlement during the summer period. The area east of the Paleapolis archaeological site is supplied by the Vasilikos spring.

Chora and Alonia are jointly supplied from the Askamnes and Sotiros springs. Additionally, and especially in summer, Chora is supplied from the Vrysia springs and Alonia used to be supplied from the Agios Georgios spring.

Lakoma, Makrylies and Xiropotamos are mainly supplied from the Panagia Mandalo spring. In addition, Lakoma is also served by a well located 60-70 meters from the coast.Daphnes - Kasteli - Prophitis Elias are served by Panagia Mandalo spring.

Kato Kariotes and Ano Kariotes are supplied from different sources located at Voutiros Kapias, respectively.

Therma is mainly supplied by two springs, one south of the settlement and one east in the area Pera Therma, located near a stream. The Agios Antonios spring serves the municipal campsite. The Varades camping site is supplied by the homonymous spring.

Finally, Ano Meria is supplied by Karidies spring.

Tables 1 and 2 provide the names of Municipal springs and drillings for domestic water use, their coordinates and the settlements that they serve.

Table 1. Names (terminology according to the Municipality) and coordinates of municipal springs for domestic use and the settlements that they serve

\begin{tabular}{|c|c|c|c|c|}
\hline Settlement & Spring & $\mathbf{X}$ & $\mathbf{Y}$ & Map code \\
\hline \multirow{4}{*}{ Chora } & Vrysia 1 & 629666.8497 & 4480856.464 & S1 \\
\hline & Vrysia 2 & 629598.5171 & 4480904.358 & S2 \\
\hline & Varades & 631648.3359 & 4480143.912 & S3 \\
\hline & Sotiros & 629365.5367 & 4480450.611 & S4 \\
\hline \multirow{3}{*}{ Alonia } & Ag. Georgios (not operating) & 629549.5219 & 4480159.543 & S5 \\
\hline & Varades & 631648.3359 & 4480143.912 & S3 \\
\hline & Sotiros & 629365.5367 & 4480450.611 & S4 \\
\hline \multirow{4}{*}{ Kamariotissa } & Ag. Theodoros & 629608.8522 & 4482615.663 & S6 \\
\hline & Kopsi & 629432.5142 & 4483510.364 & S7 \\
\hline & Skra (Axios 1) & 629796.4439 & 4484621.645 & S8 \\
\hline & Skra (Axios 2) & 629802.2152 & 4484626.075 & S9 \\
\hline \multirow{4}{*}{ Palaeapoli } & Ag. Theodoros & 629608.8522 & 4482615.663 & S6 \\
\hline & Kopsi & 629432.5142 & 4483510.364 & S7 \\
\hline & Skra (Axios 1) & 629796.4439 & 4484621.645 & S8 \\
\hline & Skra (Axios 2) & 629802.2152 & 4484626.075 & S9 \\
\hline Vasilikos & Vasilikos & 631665.3378 & 4484432.515 & S10 \\
\hline $\begin{array}{c}\text { Kato } \\
\text { Kariotes }\end{array}$ & Voutiros & 635664.0034 & 4483684.829 & S11 \\
\hline Ano Kariotes & Kapias & 634031.9095 & 4483370.863 & $\mathrm{~S} 12$ \\
\hline Therma & Therma & 635627.3455 & 4483584.112 & S13 \\
\hline
\end{tabular}




\begin{tabular}{|c|c|c|c|c|}
\hline \multirow{7}{*}{} & Milia & 635462.5395 & 4483472.187 & S14 \\
\cline { 2 - 5 } & Askamnes & 631178.9382 & 4479847.399 & S15 \\
\cline { 2 - 5 } & $\begin{array}{c}\text { Road towards summit Fegari } \\
\text { (pump) }\end{array}$ & 636532.3608 & 4483345.313 & S16 \\
\cline { 2 - 5 } & $\begin{array}{c}\text { Pathway towards summit } \\
\text { Fegari (pipe) }\end{array}$ & 636532.3608 & 4483345.313 & S17 \\
\hline \multirow{3}{*}{ Pera Therma } & Svotana & 636569.0634 & 4483382.74 & S18 \\
\cline { 2 - 5 } & Grigorakis & 637013.9572 & 4482648.999 & S19 \\
\hline Varades & Ag. Antonios & 638554.7755 & 4482494.196 & S20 \\
\hline Ano Meria & Kandour (Kardies) & 640808.3452 & 4479314.753 & S21 \\
\hline Makrylies & Terzis' mill & 628963.3713 & 4477756.516 & S22 \\
\hline \multirow{2}{*}{ Xiropotamos } & Panagia Mandalou & 631059.7112 & 4476752.616 & S23 \\
\cline { 2 - 5 } & Terzi'smill & 628963.3713 & 4477756.516 & S22 \\
\hline \multirow{2}{*}{ Lakoma } & Panagia Mandalou & 631059.7112 & 4476752.616 & S23 \\
\cline { 2 - 5 } & Macrylies beach (well) & 628269.1335 & 4475842.496 & S14 \\
\hline Profitis Elias & Panagia Mandalou & 631059.7112 & 4476752.616 & S23 \\
\hline Kasteli & Panagia Mandalou & 631059.7112 & 4476752.616 & S23 \\
\hline Dafnes & Panagia Mandalou & 631059.7112 & 4476752.616 & S23 \\
\hline
\end{tabular}

Table 2. Names (terminology according to the Municipality) and coordinates of municipal drillings for domestic use and the settlements that they serve

\begin{tabular}{|c|c|c|c|c|}
\hline Settlement & Drilling & $\mathbf{X}$ & $\mathbf{Y}$ & Map code \\
\hline Alonia & Sklavouna & 626407.72 & 4480006.55 & D1 \\
\hline Kamariotissa & Lagada (Trypa) & 625791.43 & 4481454.14 & D2 \\
\hline
\end{tabular}

Regarding irrigation, the Municipality manages 16 groundwater drillings, of which two are nowadays inactive (Table 3, Figure 5). Since 2015, the Municipality applies a system with electronic hydrometers, where each farmer uses a card to activate water abstraction from the drillings. On each card the time of water consumption is registered. According to the former mayor Athanasios Vitsas, this system substantially reduced water use from the drillings, as users have to pay 2.6 Euro per hour. Unfortunately, the disastrous flood of September 2017 destroyed all respective files and thus data on groundwater abstraction are not available for the years 2015-2017.

Table 3. Names (terminology according to the Municipality) and coordinates of municipal drillings for irrigation and the settlements that they serve

\begin{tabular}{|c|c|c|c|c|}
\hline \multirow{3}{*}{ Settlement } & Drilling & $\mathbf{X}$ & $\mathbf{Y}$ & $\begin{array}{c}\text { Map } \\
\text { Code }\end{array}$ \\
\hline \multirow{3}{*}{ Kamariotissa } & Aj. Kara & 624827.677 & 4479927.1 & D3 \\
\cline { 2 - 5 } & Lagada (Trypa) & 626097.944 & 4481032.5 & D2 \\
\cline { 2 - 5 } & Mavrou (not operating) & 624544.175 & 4480137.5 & D4 \\
\hline \multirow{3}{*}{ Alonia } & Ag. Dimitrios 1 & 625580.418 & 4479554.8 & D5 \\
\cline { 2 - 5 } & Ag. Dimitrios 2 & 625872.386 & 4479457.1 & D6 \\
\cline { 2 - 5 } & Tzigkounas & 626310.14 & 4478996.8 & D7 \\
\hline
\end{tabular}




\begin{tabular}{|c|c|c|c|c|}
\hline & Panagouda & 625968.562 & 4478967.2 & D8 \\
\hline \multirow{3}{*}{ Alonia } & Sait Arch & 627351.74 & 4479470.4 & D9 \\
\cline { 2 - 5 } & Sykia & 625421.535 & 4479255.9 & D10 \\
\hline \multirow{4}{*}{ Lakoma } & Apatsanades & 626683.269 & 4477985.5 & D11 \\
\cline { 2 - 5 } & Ochtos & 627227.849 & 4477447.4 & D12 \\
\cline { 2 - 5 } & Alanoudia & 627741.0 & 4476470 & D13 \\
\hline \multirow{2}{*}{ Makrylies } & Tiganouria & 628013.0 & 4476298.6 & D14 \\
\hline \multirow{3}{*}{ Pachia Ammos } & Koitada 1 & 631597.584 & 4473869 & D15 \\
\cline { 2 - 5 } & Koitada 2 & 631775.781 & 4473900.4 & D16 \\
\cline { 2 - 5 } & Mellagki (not operating) & 626270.188 & 4481869.4 & D17 \\
\hline
\end{tabular}

Besides municipal drillings used for irrigation, farmers install their own boreholes or dig wells within their properties to irrigate their fields. They may additionally install km-long PVC pipes to transfer water from neighboring springs or streams. To obtain the rights for exploiting water resources, farmers are obliged to submit a statement that includes, among others, the source type of water used, the coordinates of the water abstraction points, the type and area of cultivation to be irrigated, the irrigation system, the irrigation period, and the minimum and maximum water use. Nevertheless, illegal surface water abstraction is considered immense. According to the respective licenses, farmers abstract privately water from 9 wells, 7 drillings, and two stream reaches, whereas in two cases there are no data on the source and the amounts of water used.

Table 4 provides data on the private water abstraction points.

ble 4. Ground and surface water abstraction points used privately for irrigation. their coordinates. the irrigation system applied, and the type and area of cultivation served $\left(1\right.$ acre $=1000 \mathrm{~m}^{2}$ - data according to water use licenses provided by the Municipality)

\begin{tabular}{|c|c|c|c|c|c|c|}
\hline $\begin{array}{c}\text { Source of } \\
\text { water }\end{array}$ & $\mathbf{X}$ & $\mathbf{Y}$ & $\begin{array}{c}\text { Map } \\
\text { code }\end{array}$ & Type of cultivation & $\begin{array}{c}\text { Irrigated } \\
\text { area (acres) }\end{array}$ & Irrigation system \\
\hline well & 626157.48 & 4478926.8 & PR1 & barley & 0.71 & Canals, artificial rain \\
\hline drilling & 625633.93 & 4478117.7 & PR2 & barley-wheat. vetch. alfalfa. olive groves & & surface irrigation \\
\hline drilling. well & 626094.37 & 4478807.1 & PR3 & olive groves & 5.5 & canals \\
\hline well & 629672.21 & 4475882.4 & PR4 & vineyard and olive groves & $1 \& 2$ & drip irrigation \\
\hline drilling & 625043.58 & 4480962.5 & PR5 & olive groves & 2.5 & artificial rain \\
\hline well & 626772.63 & 4478873.8 & PR6 & barley & 0.48 & not irrigated \\
\hline- & - & - & PR7 & olive groves & 5 & free flow \\
\hline- & - & - & PR8 & alfalfa and wheat & $5 \& 10$ & sprinkler irrigation \\
\hline well & 634356.91 & 4484494.4 & PR9 & olive groves & 6 & surface irrigation \\
\hline well & 632910.55 & 4483510.5 & PR10 & olive groves & canals - pipes \\
\hline well & 631466 & 4484927 & PR11 & & - & not irrigated \\
\hline drilling & 624669 & 4480406 & PR12 & vineyard and olive groves & $1 \& 8.5$ & drip irrigation \\
\hline drilling & 625419 & 4478776 & PR13 & cereals & 27.7 & sprinkler irrigation \\
\hline drilling & 628031.52 & 4476682.1 & PR14 & alfalfa. corn and cereals & $16.4 \& 30$ & sprinkler irrigation \\
\hline well & 625435 & 4479171 & PR15 & vegetables & 8 & drip irrigation \\
\hline well & 626901 & 4477239 & PR16 & Vineyard and olive groves & $0.79 \& 0.48$ & drip irrigation \\
\hline drilling & 628502.75 & 4475835.6 & PR17 & olive groves & 25.5 & surface and drip \\
\hline stream & 626681.88 & 4479046.3 & PR1 & olive groves & 4.5 & surface irrigation \\
\hline
\end{tabular}




\begin{tabular}{|c|c|c|c|c|c|c|}
\hline stream & 630747.14 & 4475543.3 & PR2 & olive groves and vineyard & $28.1 \& 13.2$ & drip irrigation \\
\hline
\end{tabular}

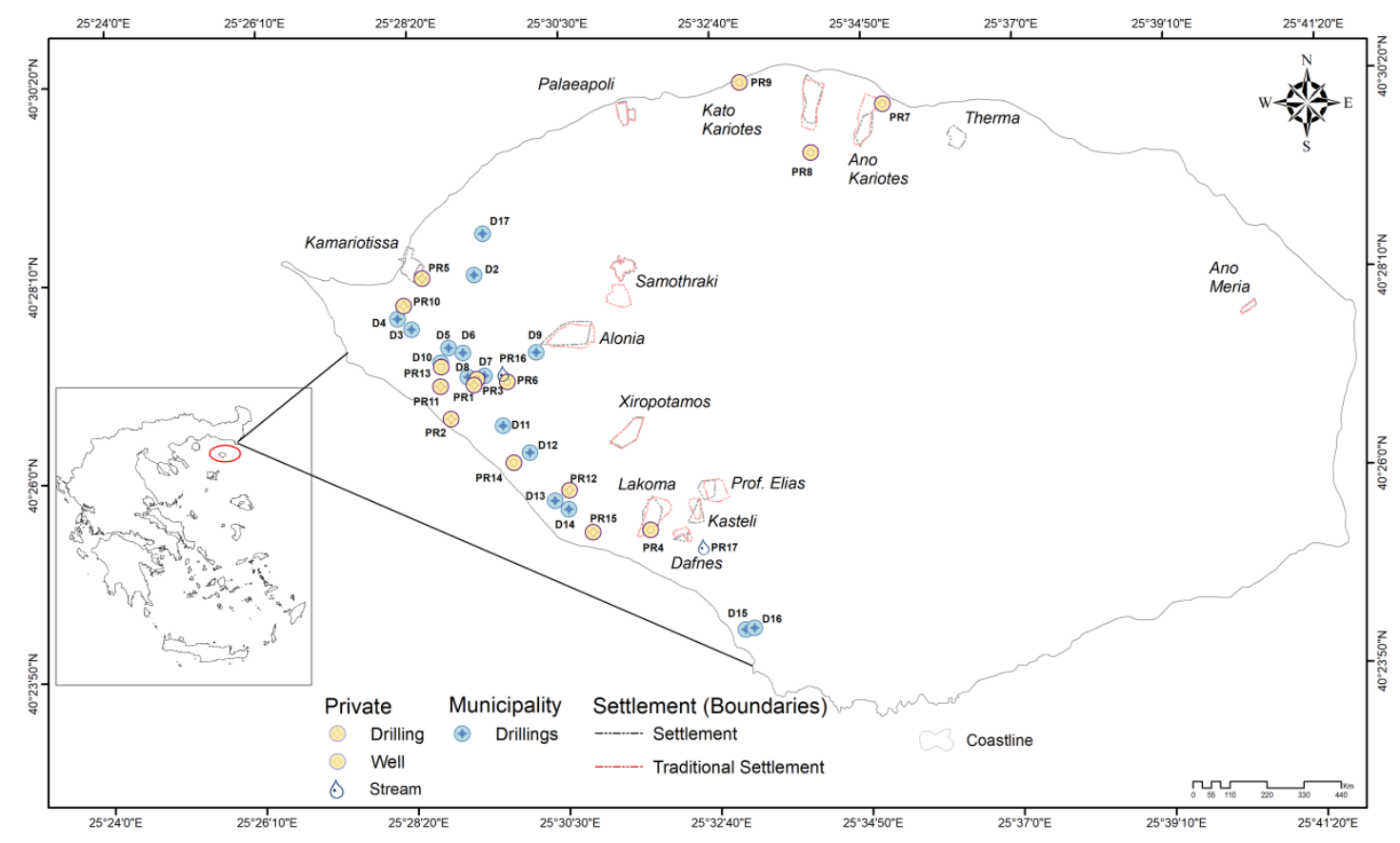

Figure 5. Water abstraction points (drillings, wells, streams) that used for irrigation on Samothraki Island.

\subsubsection{Estimation of water uses/needs}

\section{Domestic water consumption and needs}

Domestic water consumption data were provided by the Municipality for the year 2016 (Table 5). According to these data, the total annual domestic water consumption for 2016 was $371,160 \mathrm{~m}^{3}$. Note that 2016 was a particularly dry year with water shortages during summer. As a result, the long-term annual domestic water consumption should be higher.

Table 5. Water consumption in the island's settlements for 2016

\begin{tabular}{|c|c|}
\hline Settlement & Water consumption in $\mathbf{~ m}^{3} / \mathbf{y e a r}$ \\
\hline Chora & $120.395^{*}$ \\
\hline Kamariotisa & 101.308 \\
\hline Lakoma & 36.803 \\
\hline Alonia & 29.557 \\
\hline Therma & 25.528 \\
\hline Profitis Elias & 19.090 \\
\hline Palaeapoli & 14.942 \\
\hline Kato Kariotes & 12.914 \\
\hline Xiropotamos & 9.413 \\
\hline Ano Meria & 7.072 \\
\hline
\end{tabular}




\begin{tabular}{|c|c|}
\hline Makrylies & 6.742 \\
\hline Ano Kariotes & 4.577 \\
\hline Total & $\mathbf{3 7 1 . 1 6 0}$ \\
\hline
\end{tabular}

* $31.206 \mathrm{~m}^{3} /$ year are from flowmeter measurements and $89.189 \mathrm{~m}^{3} /$ year from estimations by the Municipality

Furthermore, the domestic water consumption has been compared with the domestic water needs. Considering a mean daily water use of $250 \mathrm{~L} /$ capita and the population of the island $(2,859$ citizens in 2011 ), the total water needs of the permanent population is estimated at $260,884 \mathrm{~m}^{3} / \mathrm{yr}$. Tourist arrivals are estimated to 36,000 per year (for 2015) with an average stay of 4.79 days (Schwaiger 2017). According to these numbers, touristic needs reach $43,110 \mathrm{~m}^{3} / \mathrm{yr}$. Hence, the total domestic water needs are estimated to $303,994 \mathrm{~m}^{3} / \mathrm{yr}$. However, if we consider a more realistic domestic water consumption per capita of 129 L/day, as reported for the city of Alexandroupolis (Gratziou et al. 2006), the total domestic water needs in Samothraki decreases to $156,860 \mathrm{~m}^{3} / \mathrm{yr}$. This number is not much different from the estimations of Schoder et al (2016), i.e. $178,523 \mathrm{~m}^{3} / \mathrm{yr}$. From the above estimations, it may be concluded that domestic water consumption on the island overwhelms the respective needs by a factor of $\sim 2.3$.

Based on data of the Municipality, Romaidis (2006) reported a domestic water use of 425,955 m³ $/ \mathrm{yr}$ and calculated the needs at $323,390 \mathrm{~m}^{3} / \mathrm{yr}$ (using $250 \mathrm{~L} /$ day*capita). According to the RBMPs of Thrace Hydrological District, the groundwater abstraction for domestic use alone is estimated to be about $860,000 \mathrm{~m}^{3} / \mathrm{yr}$. This number is considered not realistic. Finally, Karavitis \& Kerkides (2002) provided an indicative water demand for domestic use of $500,000 \mathrm{~m}^{3} / \mathrm{yr}$.

\section{Irrigation water use and needs}

Figure 6 presents the land use map according to CORINE (2006). As a result of the mountainous relief of the island, agricultural land is restricted. Cultivated area numbers vary depending on the literature source ${ }^{5}$. According to the data of the Municipality for 2017 , the total cultivated area reached $29.69 \mathrm{~km}^{2}$ ( $16.7 \%$ of the island's area), of which $29.66 \mathrm{~km}^{2}$, i.e. $99.9 \%$, is irrigated.

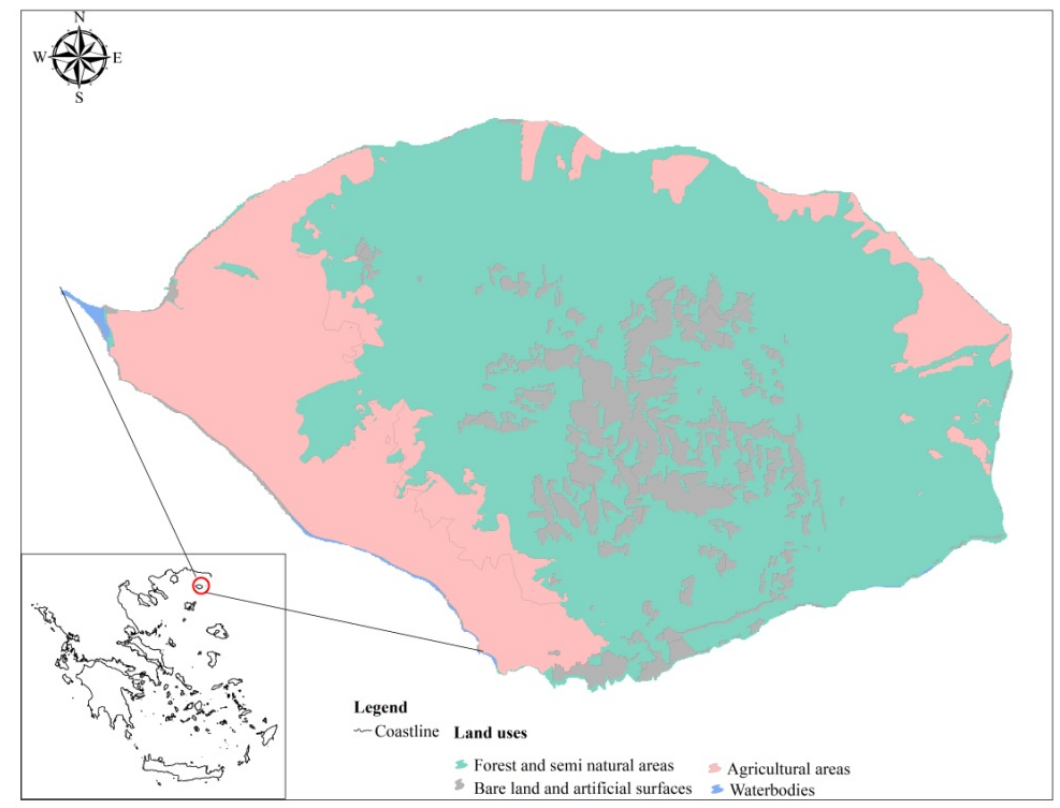

Figure 6. Land use map of Samothraki Island according to CORINE (2006)

Data on real water uses for agriculture are missing. Regarding Municipal drillings serving irrigation needs, existing information refers to the discharge of each drilling (Table 6) and the operation time of

\footnotetext{
${ }^{5} 24.6 \mathrm{~km}^{2}$ (CORINE. 2006), $30.8 \mathrm{~km}^{2}$ (NoSI, 2011) and $45.7 \mathrm{~km}^{2}$ (Hellenic Statistical Service. 2011)
} 
all drillings together. Regarding private water uses for irrigation, data on water withdrawal, obtained from the respective licenses, are only theoretical (Table 7).

For Municipal boreholes, the total operation time of all drillings together in 2018 was 3,716 hours. Groundwater abstraction for irrigation from Municipal drillings during 2018 is estimated at 1,631,324 $\mathrm{m}^{3}$. This number derives from the data of Table 6 , by multiplying the average discharge of the drillings $\left(31.4 \mathrm{~m}^{3} / \mathrm{h}\right)$ with the number of operating drillings (14) and the total operation time (3,716 hours).

Regarding private with drawls, irrigation requirements range between 106,069 and 147,948 $\mathrm{m}^{3} / \mathrm{yr}$ (average $127,008 \mathrm{~m}^{3} / \mathrm{yr}$ ), of which 82,029 to $127,458 \mathrm{~m}^{3} / \mathrm{yr}$ (average $104,743 \mathrm{~m}^{3} / \mathrm{yr}$ ) derive from groundwater sources (Table 7).

As a result, the total (municipal and private) mean annual water abstraction for irrigation purposes (focusing on 2018) reaches $1,758,332 \mathrm{~m}^{3} / \mathrm{yr}$, of which $1,736,067 \mathrm{~m}^{3} / \mathrm{yr}$ refers to groundwater.

According to the RBMPs of Thrace Hydrological District, the total mean annual groundwater abstraction for irrigation is $1,660,000 \mathrm{~m}^{3}$.

Keeping in mind that, in common practice, stream or spring runoff are substantial sources of unregistered irrigation water on the island, an effort has been made to estimate total irrigation water abstraction needs by employing the area of the different cultivation types applied on the island (respective data were provided by the Municipality for 2017) considering the irrigation needs of each crop type. The calculation procedure is presented in the Appendix I (Tables 1A-7A). The water requirements for different crop categories are defined in Law 16/6631/89. particularly for the Thrace Hydrological District. Since irrigation on the island is largely applied by a mixture of surface water application, sprinkler, and drip irrigation, the irrigation efficiency was set to $85 \%$ according to respective data provided by the Law. Water distribution in Samothraki is applied either through traditional open channels or via PVC pipes. To calculate irrigation losses due to the water distribution system we used the numbers provided in Law 16/6631/89, i.e. 5\% losses for pipes and $10 \%$ for open irrigation channels, and assumed (after discussions with the Municipality's Technical Service staff) that $75 \%$ of irrigation on the island is carried out through pipes. Finally, the irrigation period according to the Municipality is June-September and irrigation covers the entire months.

According to this approach, the annual water requirements for irrigation range between 13.93 and 16.93 $\mathrm{hm}^{36}$, with an average of $15.43 \mathrm{hm}^{3}$. Schoder et al. (2016) estimated the potential water demand for irrigation at $7.22 \mathrm{hm}^{3} / \mathrm{yr}$. These numbers are immense compared to the estimated annual water use for irrigation $\left(1.76 \mathrm{hm}^{3}\right)$, which is 8.8 times lower than the theoretical crop needs.

Table 6. Municipality irrigation drillings and their discharge in $\mathrm{m}^{3} / \mathrm{h}$

\begin{tabular}{|c|c|c|}
\hline Drilling & Discharge $\left(\mathrm{m}^{3} /\right.$ hour $)$ & \multirow{2}{*}{ Settlement } \\
\cline { 1 - 2 } Ag. Kara & 20 & \multirow{2}{*}{ Kamariotissa } \\
\cline { 1 - 2 } Trypa* & 50 & \\
\cline { 1 - 2 } Mavrou & not operating & \multirow{2}{*}{ Alonia } \\
\cline { 1 - 2 } Ag. Dimitrios 1 & 25 & \\
\cline { 1 - 2 } Ag. Dimitrios 2 & 50 & \multirow{2}{*}{ Alonia } \\
\cline { 1 - 2 } Tzigkounas & 50 & \multirow{2}{*}{ Lakoma } \\
\cline { 1 - 2 } Panagouda & 35 & \\
\cline { 1 - 2 } Sait Arch & 40 & \\
\cline { 1 - 2 } Sykia & 40 &
\end{tabular}

${ }^{6} 1 \mathrm{hm}^{3}=1,000,000 \mathrm{~m}^{3}$ 


\begin{tabular}{|c|c|c|}
\cline { 2 - 2 } Alanoudia & 15 & \multicolumn{1}{|c|}{ Makrylies } \\
\hline Tiganouria & 10 & \multirow{2}{*}{ Pachia Ammos } \\
\hline Koitada 1 & 12 & \\
\hline Koitada 2 & 12 & \\
\hline Mellagki & not operating & \\
\hline
\end{tabular}

* gas station

Table 7. Maximum and minimum water withdrawal from private boreholes, wells and surface water (data according to water use licenses. GW: groundwater. SW: surface water). The additional details are provided in Table 4.

\begin{tabular}{|c|c|c|}
\hline $\begin{array}{l}\text { Source of } \\
\text { water }\end{array}$ & $\begin{array}{c}\text { Maximum annual } \\
\text { water withdrawal } \\
\left(\mathrm{m}^{3} / \mathbf{y r}\right)\end{array}$ & $\begin{array}{c}\text { Minimum annual } \\
\text { water withdrawal } \\
\left(\mathbf{m}^{3} / \mathbf{y r}\right)\end{array}$ \\
\hline well & 284 & 213 \\
\hline drilling & - & - \\
\hline drilling. well & 400 & 200 \\
\hline well & 200 & 150 \\
\hline drilling & 200 & 100 \\
\hline well & 0 & 0 \\
\hline well & 4176 & 3488 \\
\hline well & - & - \\
\hline well & - & - \\
\hline drilling & 4160 & 3408 \\
\hline drilling & 21408 & 3700 \\
\hline drilling & 80000 & 60000 \\
\hline well & 4000 & 500 \\
\hline well & 200 & 150 \\
\hline drilling & 12430 & 10120 \\
\hline \multirow{2}{*}{ SUM GW } & 127.458 & 82.029 \\
\hline & \multicolumn{2}{|c|}{ Average 104.743} \\
\hline stream & 2490 & 2040 \\
\hline stream & 18000 & 22000 \\
\hline \multirow{2}{*}{ TOTAL } & 147.948 & 106.069 \\
\hline & \multicolumn{2}{|c|}{ Average 127.008} \\
\hline
\end{tabular}




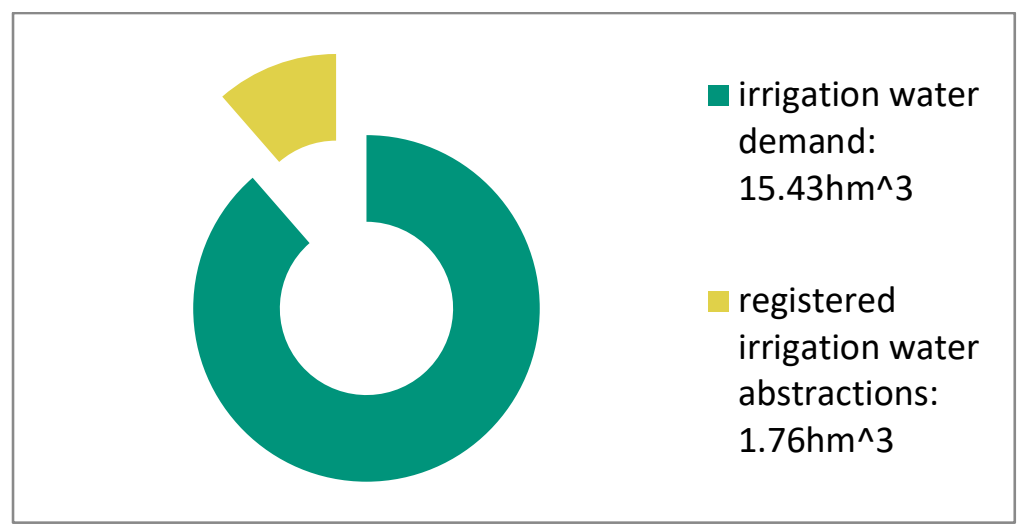

Figure 6. Comparison between irrigation water use (estimated according to data provided by the Municipality of Samothraki) and the theoretical irrigation demand, estimated according to the area and the water requirements of the different cultivation types, the irrigation period, the irrigation systems applied, and the theoretical irrigation losses.

\section{Livestock water needs}

Data related to water use by livestock are missing. We thus calculated livestock water needs. According to http://provata-assaf.blogspot.com/2013/05/blog-post_7.html, the mean water consumption for sheep has been estimated to $5 \mathrm{~L} /$ day. For goats, a mean value of $2.54 \mathrm{~L} /$ day has been applied according to the average of different literature sources summarized in Anthitsa et al. (2017). The latter authors provide a value of $37.5 \mathrm{~L} /$ day for horses. Considering the number of animals according to data from the Municipality for 2017, the estimated water consumption for livestock reaches $60,444 \mathrm{~m}^{3} /$ year (Table 8 ). According to the RBMPs, the annual groundwater use for livestock is estimated at $90,000 \mathrm{~m}^{3}$.

Table 8. Water consumption according to livestock type (data Municipality of Samothraki for 2017)

\begin{tabular}{|c|c|c|c|c|}
\hline Livestock type & $\begin{array}{l}\text { Livestock } \\
\text { number }\end{array}$ & $\begin{array}{c}\text { Average water } \\
\text { consumption per } \\
\text { livestock type } \\
\text { (L/day) }\end{array}$ & $\begin{array}{c}\text { Total Water } \\
\text { consumption } \\
\text { (L/day) }\end{array}$ & $\begin{array}{r}\text { Total Water } \\
\text { consumption } \\
\left(\mathbf{m}^{3} / \text { year }\right)\end{array}$ \\
\hline sheep & 18,735 & & & \\
\hline small sheep & 1,220 & & & \\
\hline rams & 581 & & & \\
\hline sum & 20,536 & 5 & 102,680 & 38,505 \\
\hline goats & 20,920 & & & \\
\hline small goats & 1,188 & & & \\
\hline mail goats & 544 & & & \\
\hline sum & 22,652 & 2.5 & 56,630 & 21,236 \\
\hline horses & 50 & 37.5 & 1,875 & 703 \\
\hline Total & & & & 60,444 \\
\hline
\end{tabular}

\section{Total water needs}

By summing up the water needs for irrigation, domestic and livestock, results an average total figure of $15.65 \mathrm{hm}^{3} / \mathrm{yr}$, whereas irrigation demands make up around $98.6 \%$ of the total water needs (domestic and livestock needs comprise 1 and $0.4 \%$, respectively). 


\subsubsection{Estimation of water resources availability}

The design and management of water resources necessarily needs a preliminary assessment of water demands and water availability. Estimation of water resources availability is an essential step for devising efficient water resources management strategies.

\section{Springs}

IGME registered 42 cold springs located at low and mid altitudes of Samothraki Island. Despite their low permeability, the magmatic rocks of the island (predominately ophiolites and secondarily granites and volcanic rocks) host 33 springs $^{7}$ (Vergis 1984, 1986) developed within cracked type aquifers (see 3.2.1). This is the result, of intense tectonic activity which caused rock fracturing and cracking enabling the formation of small ground water aquifers within rock fractures and valleys and ravines filled up with weathered material of these rocks.

The majority of these springs (18) are located within ophiolitic rocks. They are predominately contact springs between ophiolites and the Quaternary deposits (such as П-3 to П-9 and П-11, П-13 and П-14, see Fig. 7). Some springs (located between Chora and Profitis Elias, i.e. П-20 to П-24) also draining ophiolites are overflow springs, while 11 small springs located within granitic (П-31 to П-40) and two within volcanic rocks (П-16 and П-19) are fracture type springs (Vergis 1986). The mean annual discharge of springs developed within ophiolites range between 0.65 and $19.5 \mathrm{l} / \mathrm{sec}$ and show low seasonal variability. The mean annual discharge of springs located within granite rocks range between 0.1 and $6.5 \mathrm{l} / \mathrm{sec}$, while volcanic rock host two springs with 0.3 and $5.41 / \mathrm{sec}$ (Vergis 1984,1986 ).

In addition, 9 contact springs are connected with sedimentary groundwater aquifers located at the western lowland parts of the island (IGME), the so called "Xiropotamos ground water system" (RBMP 2017, see 3.2.1). These aquifers are located within Neogene and alluvial sediments. IGME speculates that the alluvial aquifers are laterally fed by the cracked aquifers. The mean annual discharge of these springs range between 0.6 and $15.5 \mathrm{l} / \mathrm{sec}$. Most important ones (in terms of discharge) are the Panagia Mandalo (П-30) and the Ano Panagia (П-29) with mean annual discharges of 15.5 and $9.5 \mathrm{l} / \mathrm{sec}$, respectively (Vergis 1984).

Figure 7 presents the georeferenced and registered springs according to the results of this study. It additionally shows the locations of springs studied by IGME. It should be mentioned that, since IGME did not provide coordinates, we transferred the spring sites from an IGME map. Due to technical reasons, it is possible that a number of Municipality springs may be identical to IGME springs.

Table 9 presents the spring discharge measurements according to IGME.

\footnotetext{
${ }^{7}$ The RBMPs provide a total number of 35 springs.
} 


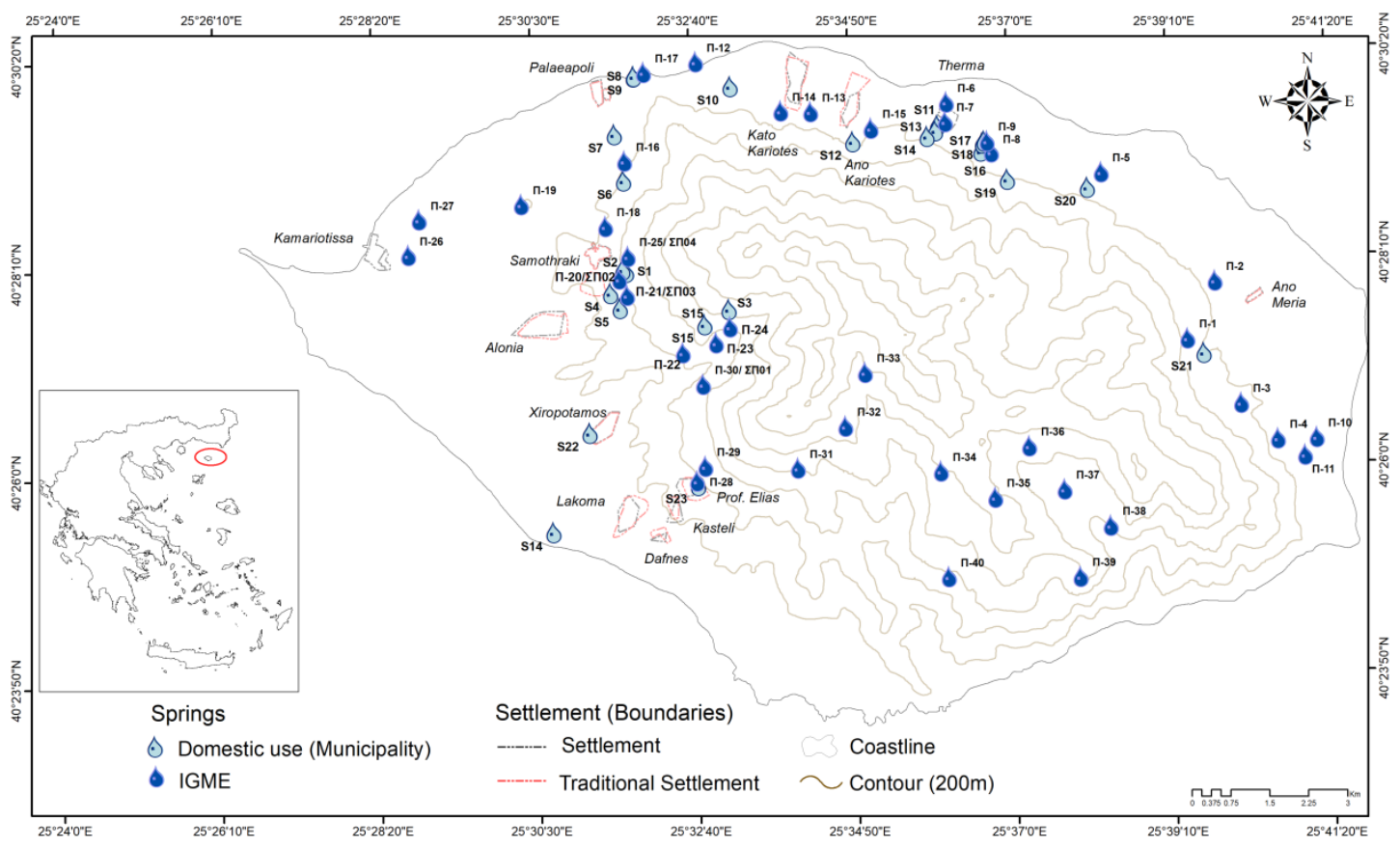

Figure 7. Topographic map of Samothraki with the location of springs exploited by the Municipality for domestic use (georeferenced and registered in the frame of this study) and the spring sites studied by IGME. Note that a number of Municipality springs may be identical to IGME springs.

Table 9. Spring discharge measurements according to IGME

\begin{tabular}{|c|c|c|c|c|}
\hline Map Code & Location & Spring Name & $\begin{array}{c}\text { Geology at } \\
\text { spring } \\
\text { outflow }\end{array}$ & $\begin{array}{c}\begin{array}{c}\text { Mean } \\
\text { discharge }\end{array} \\
\left(\mathrm{hm}^{3 /} \text { year) }\right. \\
1980-1990\end{array}$ \\
\hline$\Pi-1$ & Ano Meria & Kandaradika & Diabases & 0.683 \\
\hline$\Pi-2$ & Ano Meria & Isomata & Quaternary & 0.084 \\
\hline П-3 & Ano Meria & Kerasia & Diabases & 0.499 \\
\hline$\Pi-4$ & Ano Meria & Lithari & Diabases & 0.145 \\
\hline$\Pi-5$ & Fonias & Fonias & Diabases & 0.030 \\
\hline$\Pi-6$ & Therma & Therma & Diabases & 0.020 \\
\hline$\Pi-7$ & Therma & Sklithros & Diabases & 0.155 \\
\hline$\Pi-8$ & Therma & Svopana & Diabases & 0.150 \\
\hline$\Pi-9$ & Therma & Svopana & Diabases & 0.319 \\
\hline$\Pi-10$ & Ano Meria & Lagadiotis & Quaternary & 0.114 \\
\hline$\Pi-11$ & Ano Meria & Askamnia & Quaternary & 0.039 \\
\hline П-12 & Palaeapoli & Pyrgos & Quaternary & 0.019 \\
\hline$\Pi-13$ & Kato Kariotes & Potami & Diabases & 0.084 \\
\hline$\Pi-14$ & Kato Kariotes & Voutiros & Diabases & 0.139 \\
\hline$\Pi-15$ & Ano Kariotes & Vathra & Diabases & 0.161 \\
\hline$\Pi-16$ & Palaeapoli & Kopsi & Dacites & 0.167 \\
\hline$\Pi-17$ & Kamariotissa & Lanii & Diabases & 0.381 \\
\hline П-18 & Chora & Platanos & & \\
\hline
\end{tabular}




\begin{tabular}{|c|c|c|c|c|}
\hline П-19 & Chora & Psychonero & Dacites & 0.027 \\
\hline$\Pi-20 / \Sigma \Pi 02$ & Chora & Sotiras & Diabases & 0.613 \\
\hline П-21/ & Alonia & Ag Georgis & Diabases & 0.261 \\
\hline П-22 & Therma & Askamnes & Diabases & 0.095 \\
\hline П-23 & Alonia & Loutskia & Diabases & 0.022 \\
\hline$\Pi-24$ & Alonia & Varades & Diabases & 0.365 \\
\hline П-25/ ऽП04 & Chora & Vrysia & Diabases & 0.032 \\
\hline$\Pi-26$ & Kamariotissa & Solinari & Quaternary & 0.025 \\
\hline П-27 & Kamariotissa & Lagada & Quaternary & 0.087 \\
\hline П-28 & Prof. Elias & Ano Panagia & Quaternary & 0.147 \\
\hline П-29 & Prof. Elias & Kato Panagia & Quaternary & 0.311 \\
\hline$\Pi-30 / \Sigma \Pi 01$ & Xiropotamos & Panagia Mandalo & Quaternary & 0.410 \\
\hline$\Pi-31$ & Pachia Ammos & Ag. Banti & Granites & 0.003 \\
\hline$\Pi-32$ & Vatos & Katsgourou & Granites & 0.114 \\
\hline$\Pi-33$ & Vatos & Bachadouri & Granites & 0.024 \\
\hline$\Pi-34$ & Vatos & Krio Nero & Granites & 0.020 \\
\hline$\Pi-35$ & Vatos & Latzari & Granites & 0.006 \\
\hline$\Pi-36$ & Gyali & Stravoxilo & Granites & 0.205 \\
\hline$\Pi-37$ & Gyali & Platia & Granites & 0.076 \\
\hline П-38 & Gyali & Adriomeni & Granites & 0.030 \\
\hline П-39 & Gyali & Ag. Thekla & Granites & 0.013 \\
\hline$\Pi-40$ & Vatos & Vasilitsi & Granites & 0.032 \\
\hline$\Pi-41$ & Pachia Ammos & Karavi & & \\
\hline$\Pi-42$ & Platia basin & Kalamithria & & \\
\hline \multicolumn{4}{|c|}{ Total mean annual spring discharge } & 2.916 \\
\hline
\end{tabular}

According to the data of IGME for 42 springs monitored for their discharge, the total annual discharge of theses springs reaches $2.92 \mathrm{hm}^{3}$.

Since the Municipality lacks data on discharge measurements at the spring outflows of its interest, and recent monitoring data from IGME are missing, we undertook respective measurements (see Figure 8). However, as aforementioned, this was not possible in most of the cases. Table 10 presents the discharge of the springs measured.

Table 10. Measured capacity of springs (in $\mathrm{m}^{3}$ per hour) that are being exploited by the Municipality ( 21 and 22 September 2018)

\begin{tabular}{|c|c|c|c|}
\hline Springs & $\begin{array}{c}\text { Time } \\
(\mathbf{s e c})\end{array}$ & $\begin{array}{c}\text { Water } \\
\text { quantity } \\
(\mathbf{L})\end{array}$ & $\begin{array}{c}\text { Discharge } \\
(\mathbf{L} / \mathbf{s e c})\end{array}$ \\
\hline Kopsi & 3.45 & 12.5 & 3.62 \\
\hline Aj. Theodoros & 4.6 & 7.2 & 1.57 \\
\hline Voutyros & 4.25 & 12.5 & 2.94 \\
\hline Kandour & 2.47 & 9.0 & 3.64 \\
\hline
\end{tabular}




\begin{tabular}{|c|c|c|c|}
\hline Varades (Aj. Antonios) & 21.23 & 10.0 & 0.47 \\
\hline Panagia Mandalou & 13.9 & 7.5 & 0.54 \\
\hline Askamnes & 11.99 & 10.0 & 0.83 \\
\hline
\end{tabular}

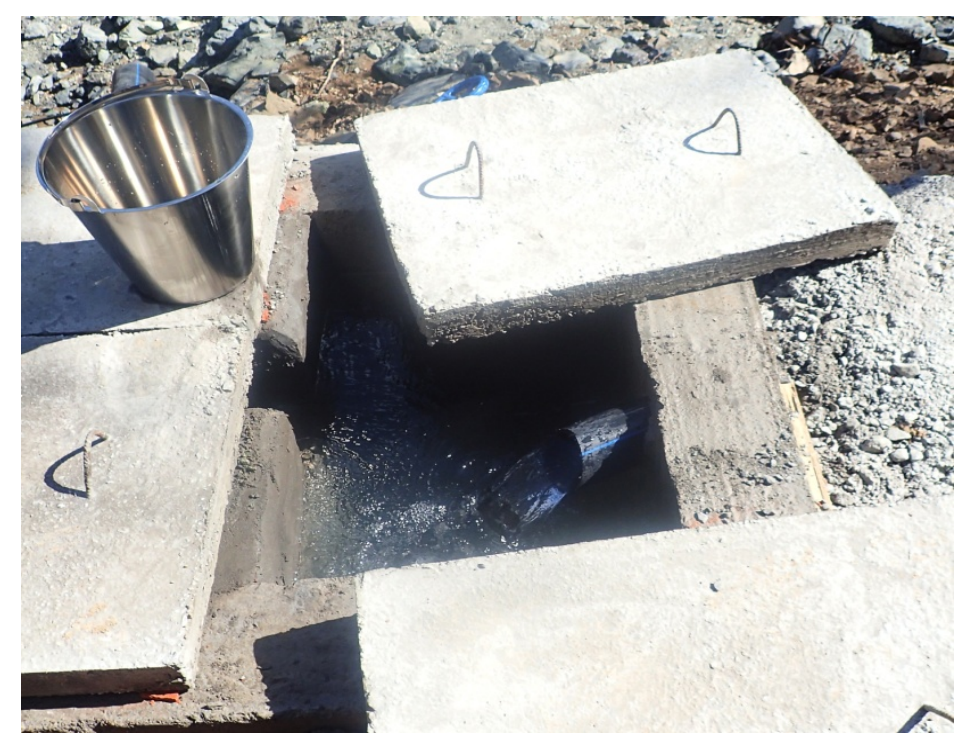

Figure 8. Spring outflow facilitating discharge measurements

Springs where discharge measurements have been performed both by IGME and HCMR were used in order to examine any long-term variations. For that purpose, we compared the old IGME measurements with the recent ones carried out in the same month. Table 11 presents the results of this comparison. According to this Table, a substantial spring discharge diminishing is clearly visible. Since the number of common springs is limited, to draw any conclusion on the possible impact of climate change or other factors (e.g. tectonic movements or human impact) on spring discharge diminishing, more measurements should be considered. However, this may be not be possible for the majority of the springs used by the Municipality as they are not accessible.

Table 11. Comparison of spring discharges between old measurements (IGME) and recent ones (HCMR)

\begin{tabular}{|c|c|c|}
\cline { 2 - 3 } \multicolumn{1}{c|}{} & \multicolumn{2}{c|}{ Spring discharge (1/s) } \\
\cline { 2 - 3 } & IGME & HCMR \\
\cline { 2 - 3 } & Average Sept 1981-83/Sept 2005-08 & September 2018 \\
\hline Panagia Mandalou & 5.43 & 0.54 \\
\hline & September 1981 & September 2018 \\
\hline Kopsi & 6.3 & 0.47 \\
\hline Varades & 11 & \\
\hline
\end{tabular}

\section{Streams}

Flow and wetted cross-section measurements were carried out near the stream outflows at the end of June 2019. The wetted cross-section was divided to subsections based on the width of each examined stream. The area and the flow of every subsection were measured and then the two measurements were multiplied in order to estimate the discharge of the corresponding subsection. To find the mean discharge of each examined stream we used the summed up the discharges of each subsection. Despite the fact that autumn and winter 2019 were rainy and snowy, a number of streams were dry. Figure 9 presents streamflow and cross-section measurements and Table 12 the results of stream discharge measurements and additionally includes discharge measurements carried out in May 2014. 

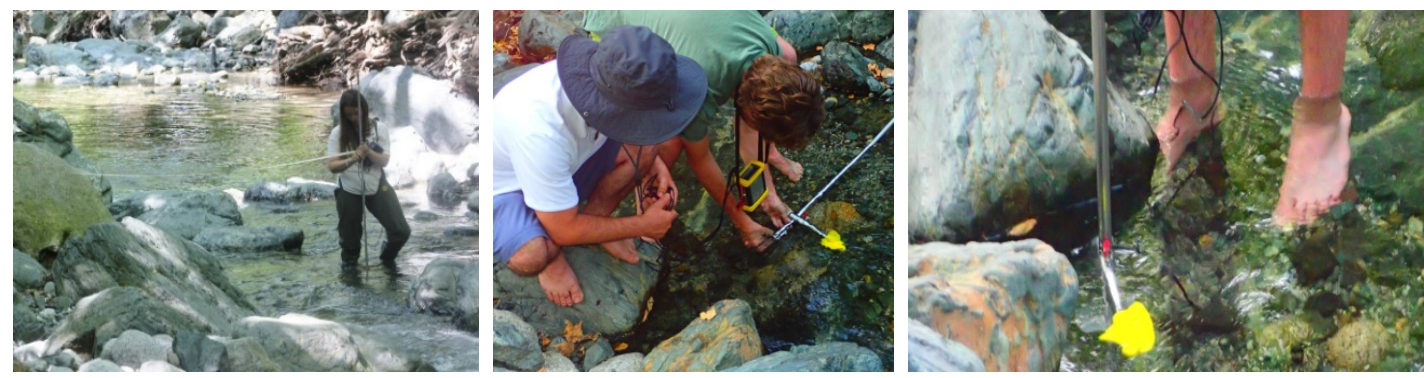

Figure 9. Streamflow and cross-section measurements

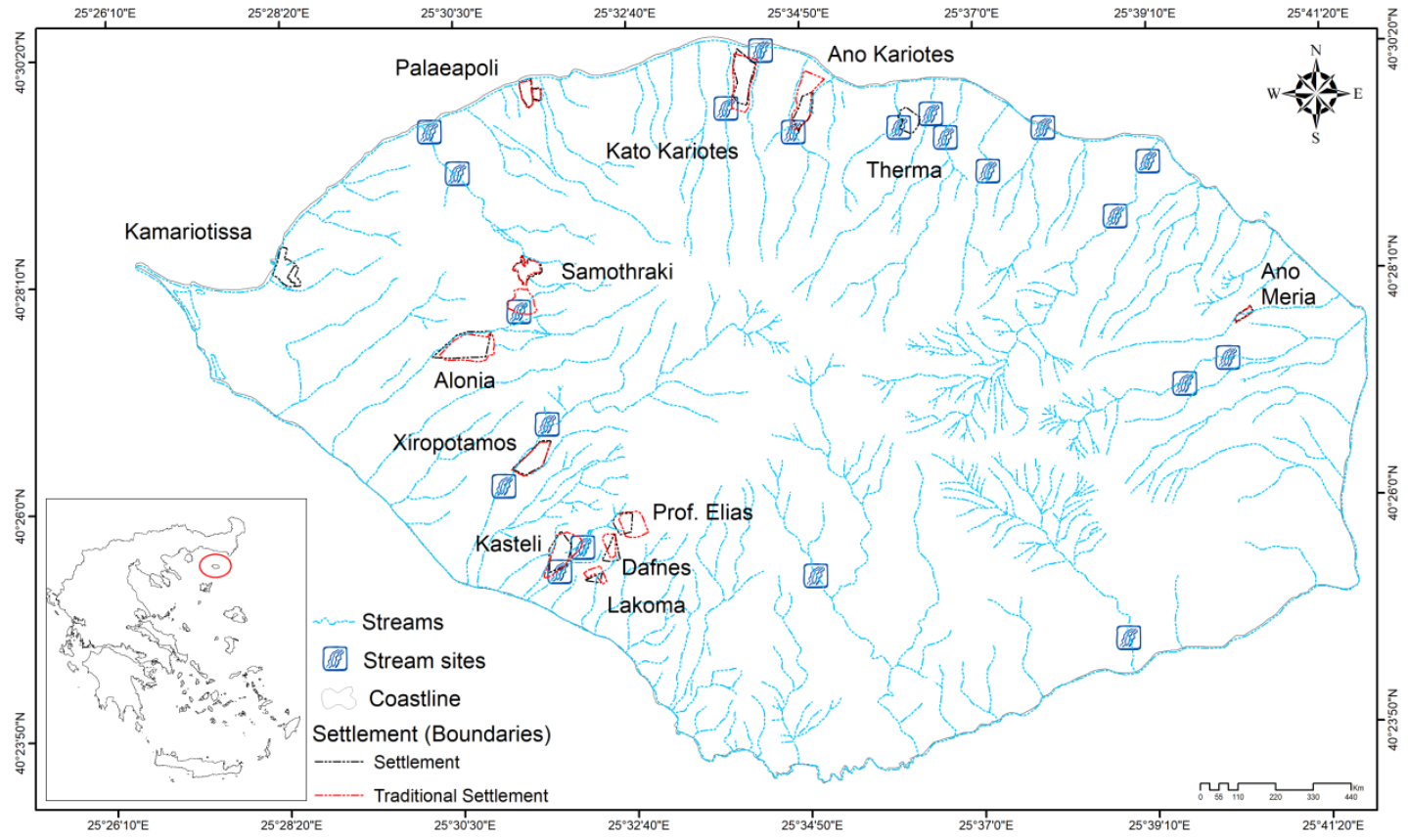

Figure 10. Stream sites were discharge measurements have been carried out.

Table 12. Stream discharge measurements (June 2019 and May 2014).

\begin{tabular}{|c|c|c|c|c|c|}
\hline \multirow{2}{*}{ River name } & \multirow{2}{*}{ Site name } & \multirow{2}{*}{$\mathbf{X}$} & \multirow{2}{*}{$\mathbf{Y}$} & \multicolumn{2}{|c|}{ Discharge $\left(\mathrm{m}^{3} / \mathrm{s}\right)$} \\
\hline & & & & May 2014 & June 2019 \\
\hline Fonias & Fonias 1 & 639300.31 & 4481826.6 & 0.396 & - \\
\hline Fonias & Fonias 2 & 639871.6 & 4483162.1 & 0.481 & 0.077 \\
\hline Platia & Gria Vathra1 & 636401.33 & 4483385.2 & 0.140 & 0.011 \\
\hline Xiropotamos & Xiropotamos gorge & 629348.22 & 4478176.7 & 0.389 & 0.027 \\
\hline Xiropotamos & Xiropotamos estuaries & 628622.7 & 4477093.6 & 0.035 & - \\
\hline Agkistros & Agistros 1 & 639969.02 & 4478746.3 & 0.359 & - \\
\hline Agkistros & Agistros 2 & 641217.72 & 4479516.8 & 0.308 & 0.026 \\
\hline Polupoudi & Alonia & 628820.78 & 4480207.5 & 0.018 & 0.005 \\
\hline Vatos & Vatos & 635241.58 & 4473556.3 & 0.409 & - \\
\hline Giali & Giali & 639637.28 & 4474405.7 & 0.360 & - \\
\hline Kardelis & Grigorakis & 637082.31 & 4482675.9 & 0.047 & 0.015 \\
\hline Katsambas & Chora & 628580.6 & 4481937.4 & 0.049 & 0.009 \\
\hline Katsambas & Katsambas estuaries & 627280.51 & 4483302.5 & 0.037 & - \\
\hline
\end{tabular}




\begin{tabular}{|c|c|c|c|c|c|}
\hline Lakoma & Lakoma 1 & 629927.41 & 4476024.4 & 0.926 & - \\
\hline Lakoma & Lakoma 2 & 629530.18 & 4475598.8 & 0.024 & 0.007 \\
\hline Arapis & Ano Kariotes & 633901.96 & 4483020.4 & 0.196 & 0.013 \\
\hline Aga (Vouturos) & Agas & 632911.46 & 4483640.5 & 0.061 & 0.002 \\
\hline Tsivdogiannis & Nekrotafeio & 636229.48 & 4483812.7 & 0.120 & 0.001 \\
\hline Thermiotis & Therma & 635678.19 & 4483506.1 & 0.052 & 0.004 \\
\hline Mantzar & Kato Kariotes & 633091.41 & 4484768.8 & - & 0.002 \\
\hline Varades & Varades & 637968.62 & 4483192.3 & - & 0.001 \\
\hline
\end{tabular}

Stream discharge differences between June 2019 and May 2014 are immense. In fact, the average stream discharge in May $2014\left(0.16 \mathrm{~m}^{3} / \mathrm{s}\right)$ is one order of magnitude higher than the June 2019 one $\left(0.016 \mathrm{~m}^{3} / \mathrm{s}\right)$. This is not caused by the meteorological conditions of the specific years; the total rainfall of the period January - May for both years is almost identical (300.2 mm for 2014 and 300.6 for 2019). The dramatic discharge diminishing from May to June is attributed to the specific properties of the cracked groundwater aquifers which are developed on magmatic rocks (see 3.3.1). These groundwater aquifers are small and shallow. As a result, only a small portion of precipitation water is stored in the subsurface and the vast portion flows as surface runoff. Thus, as rainfall inputs diminish during summer, groundwater reservoirs are rapidly exhausted and stream discharge shows a dramatic decline (Skoulikidis et al. 2019). This particular feature of the cracked groundwater aquifers of Samothraki is clearly visible during extreme rainfall events; even in summer, when groundwater aquifers are exhausted, rainfall events may cause severe floods, while soon after the event, stream flow and water level reach pre-event conditions.

Using the results of Table 12, the total annual stream discharge has been estimated. For that purpose, the average discharge of May and June of each stream has been used as an estimate of the stream's mean annual discharge. To validate our assumption, we compared the long-term mean annual discharge of Fonias and Xiropotamos provided by the Public Power Corporation (monthly measurements, period 1986-91) with our results; in both cases the discharge was the same, i.e. 0.28 and $0.21 \mathrm{~m}^{3} / \mathrm{s}$, respectively. Thus, the assumption made is realistic. By summing up the mean annual discharge of all streams, the total mean annual discharge of Samothraki streams was calculated at $62.82 \mathrm{hm}^{3}$. Nevertheless, the outflows of Giali and Vatos are situated at the southern inaccessible part of the island and it is not possible to exploit their runoff. Hence, the total exploitable annual stream discharge of Samothraki lies by $49.43 \mathrm{hm}^{3}$. Koutsogiannis et al. (2008), estimated the surface runoff of Samothraki at $48 \mathrm{hm}^{3}$.

\section{Groundwaters}

\section{Groundwater types and distribution}

Unfortunately, it was not possible to conduct pumping tests. This was because during our field work activities the municipal drillings were frequently operating to cover irrigation needs, and this would be misleading regarding the results of the pumping tests. In addition, the drillings from IGME were locked and not accessible. Thus, we based on published estimates on the available ground water resources.

According to the RBMPs groundwater is distributed within two types of aquifers:

a $66.2 \mathrm{~km}^{2}$ cracked aquifer (called according to the RBMPs, "Samothraki ground water system") that covers $3 / 4$ of the island. It is located within the weathering zone of magmatic rocks (primarily within ophiolites and secondarily within granites). It has a maximum length of $11 \mathrm{~km}$ and a maximum width of $8 \mathrm{~km}$. According to IGME (Romaidis \& Favas 2010), the cracked groundwater aquifer covers $64 \mathrm{~km}^{2}$ and receives annually $610 \mathrm{~mm}$ precipitation, and

a $25.6 \mathrm{~km}^{2}$ alluvial aquifer, located at the western part of the island, the so called "Xiropotamos ground water (GW) system" (RBMPs). According to Romaidis \& Favas (2010) the sedimentary groundwater aquifer covers $14 \mathrm{~km}^{2}$. The aquifer has a maximum length of $8 \mathrm{~km}$ and a maximum width of $5 \mathrm{~km}$. The alluvial aquifer is shallow, reaching up to $15 \mathrm{~m}$ depth (Romaidis 2006). 
In autumn, groundwater tables reach annual minima. The latter is caused by a delay between minimum precipitation and minimum runoff by one month, according to data of IGME (Romaidis2006).

Figure 11 presents all municipal and private drilling and wells found on the island. It includes those registered by the Municipality and those included in IGME database.

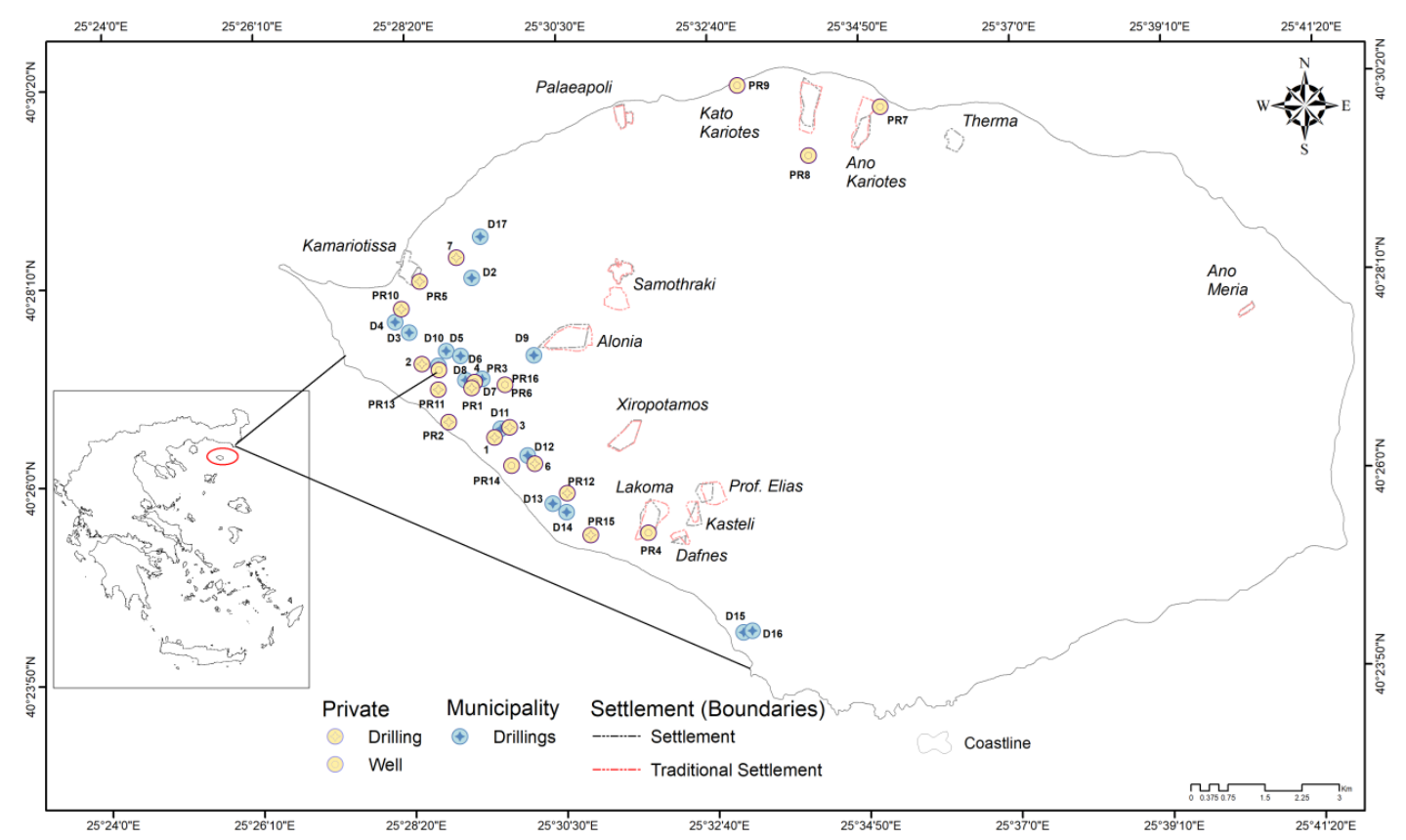

Figure 11. Total drillings on Samothraki Island (private and municipal, according to data from the Municipality and IGME. Since IGME did not georeferenced the locations, it is possible that a number of Municipality and IGME drillings are identical).

\section{Groundwater quantity}

The average annual supply of cracked aquifer is estimated at $\sim 19.8 \mathrm{hm}^{3}$ and the average annual supply of the "Xiropotamos GW system" aquifer is estimated at $\sim 1.14 \mathrm{hm}^{3}$ (RBMPs).

\section{Total available water resources}

By summing up the annual the total annual discharge of springs and streams and the annual supply of the groundwater aquifers it results that the total annual available water resources in Samothraki reach around $79.13 \mathrm{hm}^{3}$. This number is close to the $65 \mathrm{hm}^{3}$ estimated by Schoder et al. (2016) for surface runoff. Finally, it seems that the annual water supply of $90 \mathrm{hm}^{3}$ provided by the RBMPs is overestimated.

\subsubsection{Estimation of water resources quality}

\section{Domestic water disposal and treatment}

The quality of water resources is essential for their allocation to various uses, i.e. potable, irrigation or industrial use. In Samothraki water is used to cover domestic and irrigation needs. Only a local beer production plant uses water from Kamariotisa water supply system.

The Samothraki settlements are mainly served by septic cesspits. Waste water networks partly serve Chora and Lakoma. However, WWTPs do not exist yet and waste waters of these settlements end up untreated in Katsambas and Lakoma streams, respectively (Operational Program of Samothraki Municipality 2013-14).

\section{Water resources quality}

After an incident of contaminated drinking water, small chlorination facilities have been added to disinfect the cisterns used for domestic water supply (Schoder et al. 2016). The Municipal Water and Sewerage Corporation. Region of Eastern Macedonia \& Thrace in Alexandroupolis monitors the quality of the water supply system. Occasionally, the Municipality of Samothraki or private users may assign 
water analyses from the distribution system to state (Dept. of Medicine, Democritus University of Thrace; Municipal Water and Sewerage Corporation in Komotini) or private laboratories.

The vast majority of springs present excellent drinking water quality and taste and may be used as bottled water appropriate for sodium-restricted diet and diet-preventing calcium nephrolithiasis (Skoulikidis et al. 2019). The exceptionally low solute concentrations of Samothraki streams and springs is attributed to a combination of geological, morphological, and hydro(geo)logical factors. Stream basins are predominately mountainous and steep and are mostly composed by weathering resistant magmatic rocks ( $58.4 \%$ on the average). Low solute concentrations result from low-reactive bedrock and due to steep gradients and low travel time, and thus limited interaction between water and bedrock. Particularly, streams draining granitic terrains present minimum solute concentration as a result of their low weather ability, compared to the other rock types of the island. Moreover, the cracked groundwater aquifers developed in magmatic rocks are small and shallow and are composed by coarse material initiating low residence times and poor solute concentrations in subsurface flow. Thus, springs present remarkable low salt content.

\section{Springs}

A part of domestic and irrigation use is covered by cracked type aquifer springs which reveal, according to data of the IGME and the Ministry for Development, a good quality considering major ion and nutrient concentrations $^{8}$ (RBMPs). According to Romaidis (2006), spring waters are characterized soft, with low solute concentrations and are poor in metals, and thus appropriate to be used for special diets. Regarding occasional heavy metal analyses performed in the water distribution system of several settlements, the levels of $\mathrm{Fe}, \mathrm{Mn}, \mathrm{Cu}, \mathrm{Cd}, \mathrm{Ni}, \mathrm{As}, \mathrm{Pb}$ and $\mathrm{Cr}$ were far below the drinking water standards (Common Ministerial Decisions 2600/2001 and 38295/2007). Regarding nitrate and ammonia, the concentrations found in the water distribution systems were low.

According to the results of a number of microbiological analyses carried out in water samples of the domestic distribution system (provided by the Municipality of Samothraki), in some instances microbial contamination was found. For example, in July 2016, microbiological parameters (total coliforms, E. coli, enterococci, etc.) in the water distribution systems of Therma, Kato Kariotes, Alonia and Lakoma were not compliant to drinking water standards, according to the Common Ministerial Decisions 2600/2001 and 38295/2007. A second set of analyses carried out in August 2016, showed microbial contamination in the water distribution systems of Palaeapoli, Kato Kariotes, Lakoma and the camping.

HCMR examined 21 cold and two hot springs for their physicochemical and chemical characteristics (in hot springs heavy metals were additionally measured). Efforts have been made to access high altitude cold springs since they were not included in previous studies by IGME.

Table (Appendix II) presents the chemical properties of the springs examined. Cold springs were characterized by exceptional low mineralization; average total dissolved ion (TDI) concentration (excluding the outlier springs Dafnes that presented exceptionally high mineralization. and Palaeapoli that was affected by slight marine water intrusion) were several times lower compared to the mean values of 75 potable spring brands scattered throughout Greece. Moreover, when comparing average TDI of Samothraki springs with potable water springs of several European countries, it appears that the Samothraki springs reveal of the lowest mineralization in Europe. Low mineralization of Samothraki springs results from the particularly low concentrations of earth alkali and hydrogen carbonate ions; they show more than 4 times lower average total hardness than Greek potable water springs. On the contrary, as a result of abundant granitic rocks, concentrations of alkali ions, sulphate and chloride are only slightly reduced in Samothraki springs. The spring Dafnes presents an exceptional composition with high concentrations of earth alkali ions, sodium, bicarbonate, sulfate and nitrate. At the outlet of this spring salt formation is visible. In addition, the Palaeapoli spring may be occasionally affected by sea water intrusion as its relative high content in sodium and chloride indicate.

Finally, thermal springs revealed an average water temperature of $42.3^{\circ} \mathrm{C}$, an average conductivity of $18 \mathrm{mS} / \mathrm{cm}$ and an average TDI of about $9.95 \mathrm{~g} / \mathrm{L}$, of which $8.13 \mathrm{~g} / \mathrm{L}$ was represented by sodium and chloride, indicating mixing with sea water. Thermal springs that are commonly used for drinking, since

\footnotetext{
${ }^{8}$ Analyses of dissolved oxygen, $\mathrm{Cr}, \mathrm{Ni}, \mathrm{Pb}, \mathrm{Cd}, \mathrm{Al}$ and as were not included in the RBMP reports
} 
it is believed that their effects are curative, exceed the drinking water quality standards regarding manganese (Table 13).

Table 13. Heavy metal concentration of thermal springs (Skoulikidis et al. 2014)

\begin{tabular}{|c|c|c|c|c|c|c|c|c|c|}
\hline & $\begin{array}{l}\text { Mn } \\
(\mu \mathrm{g} / \mathrm{l})\end{array}$ & $\begin{array}{l}\mathrm{Fe} \\
(\mu \mathrm{g} / \mathrm{l})\end{array}$ & $\begin{array}{l}\text { Co } \\
(\mu \mathrm{g} / \mathrm{l})\end{array}$ & $\begin{array}{l}\mathrm{Ni} \\
(\mu \mathrm{g} / \mathrm{l})\end{array}$ & $\begin{array}{l}\mathrm{Cu} \\
(\mu \mathrm{g} / \mathrm{l})\end{array}$ & $\begin{array}{l}\mathrm{Zn} \\
(\mu \mathrm{g} / \mathrm{l})\end{array}$ & $\begin{array}{l}\text { Cd } \\
(\mu \mathrm{g} / \mathrm{l})\end{array}$ & $\begin{array}{l}\mathrm{Pb} \\
(\mu \mathrm{g} / \mathrm{l})\end{array}$ & $\begin{array}{l}\mathrm{Sr} \\
(\mu \mathrm{g} / \mathrm{l})\end{array}$ \\
\hline $\mathrm{T}(\mathrm{A})$ & 346.3 & 94.7 & 0.771 & 1.515 & 2.086 & 2.148 & 0.032 & 0.347 & 13880 \\
\hline $\mathrm{T}(\mathrm{B})$ & 312.3 & 159.5 & 0.651 & 1.345 & 1.642 & 6.424 & 0.028 & 0.289 & 12420 \\
\hline DWS & $50^{\mathrm{c}}$ & $300^{\mathrm{d}}$ & $20^{\mathrm{c}}$ & $20^{\mathrm{a}}$ & $20^{c}$ & $500^{c}$ & $1^{\mathrm{c}}$ & $50^{\mathrm{d}}$ & - \\
\hline
\end{tabular}

T(A). T(B): thermal springs, DWS: Drinking Water Standards, a: COUNCIL DIRECTIVE 98/83/EC, c, d: category A1, b: guide, c: mandatory, COUNCIL DIRECTIVE 75/440/EEC

\section{$\underline{\text { Streams }}$}

Like springs, streams present lower mineralization compared to Greek mainland and island rivers and streams. Like most island streams, they are enriched with sodium, chloride and silicate compared to the mainland. However, they present lower ion concentrations than other islands. Regarding nutrients, the Samothraki streams show substantially lower levels of nitrite, ammonia and phosphate, and slightly lower nitrate and total phosphorus concentrations compared to the Greek average. Table (Appendix III) presents the chemical properties of the streams examined. The physicochemical quality of Samothraki streams, according to the WFD prescriptions, is generally high. Only the Katsambas downstream Chora and the Lakoma, downstream the homonymous settlement, present a moderate quality (thus requiring remediation) due to the impact of untreated domestic wastewaters. Further downstream however, the Katsambas reaches a good quality as a result of self-purification. Finally, stream headwaters that are not affected by any pollution source, i.e. Giali and Kremasto, exhibit unexpected elevated nitrate concentrations and reveal a less than high (i.e. good) physicochemical quality. It is speculated that the high stream water nitrate levels in Samothraki result from rainwater inputs which are laden with high nutrient concentrations, as scattered rainfall analyses indicated (Skoulikidis 2019). However, this assumption should be validated by capturing and analyzing additional rain events.

\section{Groundwater}

According the RBMPs, the hydrochemical parameters of 11 drillings and two wells located in the alluvial sediment aquifers reveal low average levels, despite drilling $\Sigma Г 01$ (IGME) which shows elevated mean chloride concentration $(215.6 \mathrm{mg} / \mathrm{l} \mathrm{Cl})$, while the sulfate one $\left(350.6 \mathrm{mg} / 1 \mathrm{SO}_{4}\right)$ overwhelms drinking water standards $\left(250 \mathrm{mg} / 1 \mathrm{SO}_{4}\right)$. IGME (Romaidis \& Favas, 2010) speculates that high sulfate concentrations may be connected with the geothermal field of Therma. However, this assumption seems not realistic since other ions of geothermal origin reveal low concentrations.

The drilling used to supply water to Kamariotissa, located within Miocene sediments, reveals high nitrate concentration. Measurements carried out on demand of the Municipality presented 43.8 and 47.6 $\mathrm{mg} / \mathrm{l} \mathrm{NO}$ in the water distribution system and, according to Romaidis (2003), $51.2 \mathrm{mg} / \mathrm{l} \mathrm{NO} 3$ in the drilling used for domestic water supply whereas drinking water threshold is $50 \mathrm{mg} / \mathrm{l} \mathrm{NO}$. The same drilling may be occasionally contaminated by ammonia of anthropogenic origin, as the IGME analyses indicated $\left(0.205 \mathrm{mg} / 1 \mathrm{NH}_{4}\right.$, Romaidis 2003). Also, the drilling $\Sigma \Gamma 03$ (IGME) shows elevated mean nitrate concentration $\left(40.3 \mathrm{mg} / 1 \mathrm{NO}_{3}\right)$ (RBMPs).

Based on the results of three drilling (IGME) for the period 2005-2008, the groundwater level variation follows seasonal trends and there were no over-pumping indications. Thus, within the RBMPs, the quality of "Xiropotamos GW system" has been classified as "good". The RBMPs propose to extend groundwater monitoring by establishing two operational groundwater monitoring stations within the "Xiropotamos GW system" and one surveillance monitoring station within the cracked aquifer as the later comprise a drinking water source.

Table 14 presents the data of IGME for a number of municipal and private boreholes. It is noteworthy that in all cases the depth of the drillings, which are close to the sea, exceeds the sea level $(Z)$. This makes the groundwater vulnerable to sea water intrusion as a result of overpumping. In fact, according 
to Romaidis \& Favas (2010), the alluvial groundwater aquifer of Samothraki has started to show salinization characteristics.

Table 14. Elevation, depth and distance to the sea of drillings from IGME database.

\begin{tabular}{|c|c|c|c|c|c|c|c|c|c|}
\hline ID & $\begin{array}{c}\text { Name used by } \\
\text { Municipality }\end{array}$ & $\begin{array}{c}\text { Map } \\
\text { Code }\end{array}$ & $\mathbf{X}$ & $\mathbf{Y}$ & $\begin{array}{c}\mathbf{Z} \\
(\mathbf{m})\end{array}$ & Location & $\begin{array}{c}\text { Depth } \\
(\mathbf{m})\end{array}$ & $\begin{array}{c}\text { Discharge } \\
(\mathbf{m} \text { /h) }\end{array}$ & $\begin{array}{c}\text { Distance } \\
\text { to the } \\
\text { sea (km) }\end{array}$ \\
\hline$\Sigma \Gamma 01$ & & 1 & 626557 & 4477810 & 22 & Alonia & 80 & & 0.5 \\
\hline$\Sigma \Gamma 02$ & & 2 & 625091 & 4479294 & 12 & Alonia & 120 & 50 & 0.8 \\
\hline$\Sigma \Gamma 03$ & Mavrou & & 624480 & 4480151 & 12 & Kamariotissa & 100 & 50 & 0.7 \\
\hline 236 & & 3 & 626863 & 4478012 & 50 & Alonia & 100 & & 0.9 \\
\hline 317 & Alanoudia & & 627731 & 4476470 & 35 & Makrylies & 100 & & 0.4 \\
\hline 1128 & Ag. Dimitrios 2 & & 625875 & 4479445 & 30 & Alonia & 71 & 90 & 1.3 \\
\hline 1137 & & 4 & 626309 & 4478988 & 30 & Alonia & 117 & 80 & 1.3 \\
\hline 1139 & Trypa & & 626056 & 4481031 & 45 & Alonia & 102 & 150 & 1.4 \\
\hline 1144 & Tiganouria & & 628016 & 4476309 & 40 & Kamariotissa & 54 & 10 & 0.5 \\
\hline 1145 & Ochtos & & 627225 & 4477453 & 45 & Alonia & 111 & 40 & 0.7 \\
\hline 1147 & & 5 & 625732 & 4478907 & 15 & Alonia & 117 & 90 & 0.8 \\
\hline 1149 & Ag. Dimitrios 1 & & 625573 & 4479567 & 25 & Alonia & 102 & 120 & 1.2 \\
\hline 1152 & Mellagki & & 626328 & 4481876 & 38 & Kamariotissa & 104 & 15 & 1.0 \\
\hline 2160 & Aj. Kara & & 624811 & 4479931 & 30 & Alonia & 18 & 80 & 1.1 \\
\hline 2161 & Sait Arch & & 627397 & 4479530 & 55 & Alonia & 140 & & 2.3 \\
\hline 2162 & Sykia & & 625427 & 4479255 & 25 & Alonia & & & 0.9 \\
\hline 3334 & & 6 & 627372 & 4477276 & 20 & Alonia & 100 & 10 & 0.7 \\
\hline 3422 & & 7 & 625781 & 4481447 & 65 & Kamariotissa & 80 & 30 & 1.0 \\
\hline 3594 & & 8 & 625817 & 4482168 & 15 & Potamia & 60 & 20 & 0.5 \\
\hline & & & & & $\mathbf{3 3}$ & & $\mathbf{9 3}$ & $\mathbf{5 9}$ & \\
\hline
\end{tabular}

Groundwater extraction at rates exceeding up-stream recharge by freshwater allows the salt/freshwater interface (Figure 12) to progress inland and may cause locally increased upward and landward flow of saline seawater. Future sea level rise connected with climate change may act synergetic. Fresh water that is contaminated by only $5 \%$ of seawater renders it unsuitable for many uses. Once seawater intrudes and causes coastal salinization, it is almost impossible to remediate.

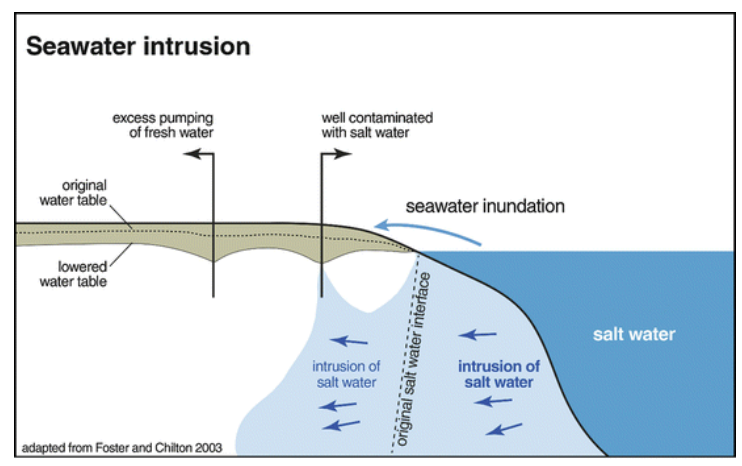

Figure 12. Salinization process of fresh groundwater in coastal aquifers due to the intrusion of saltwater from the sea as a result of over pumping. 


\subsubsection{Preliminary water resources management plan}

\section{Description of the current situation}

\section{General aspects}

Within the Regional Planning Framework and Sustainable Development of Eastern Macedonia \& Thrace (2014), Samothraki is recognized as a "Landscape of International Importance". A strategy to highlight, protect and sustainably manage the island includes:

The creation and promotion of a distinct identity of the island in Greece and internationally, by promoting exclusively mild, alternative tourism, including nautical tourism, in combination with primary production and the organization of activities targeting to recreation, culture and science.

The sound and sustainable management of the island's natural and cultural environment by restricting tourist development facilities in specific, limited areas of the island.

The management aspects of the Open City Spatial and Residential Planning of Samothraki Municipality include the:

- Rational and integrated water resources management.

- Maintenance and restoration of a free zone along the banks of all streams.

- Protection and preservation of exceptional and rare landscapes under pressure.

In addition, the streams and their riparian zones are defined as areas for protection and sustainable management; in these areas, the plane forests should be conserved, and the previously existing forest vegetation should be restored.

\section{Specific aspects}

Besides the fact that the estimations within this study basically base on theoretical water demand data (as real data on actual water uses are largely missing) which may refer to different hydrological years (lying however between 2016 and 2018), thus including a relative uncertainty, it is safely to conclude that the registered water uses $\left(1.76 \mathrm{hm}^{3}\right)$ are far less than real water demands $\left(15.65 \mathrm{hm}^{3}\right.$ on the average). As the registered water uses for irrigation largely comprise groundwater sources (registered surface water sources make up only $1.3 \%$ of water used for irrigation), it is concluded that the difference is mainly covered by illegal surface water abstraction (either from streams or springs) for irrigation.

Our estimations on the total annual available water resources $\left(\sim 76.21 \mathrm{hm}^{3}\right)$ and the total annual water demands $\left(\sim 15.65 \mathrm{hm}^{3}\right)$, show that that the island has more than adequate water resources. In order to expand irrigation, a small reservoir is being constructed at Xiropotamos stream, foreseen to store the winter flow of this intermittently dry watercourse behind a $15 \mathrm{~m}$ high dam shortly upstream of Xiropotamos village. The reservoir with a storage capacity of $315.000 \mathrm{~m}^{3}$ was designed to irrigate 70 to 100 ha of land (Vardoulakis 2011).

Despite high water availability, water shortages may occur during the summer period; for example, during the dry summer of 2006, settlements located at high altitudes faced frequent water interruptions for specific hours of the day, while according to Athanasios Vitsas, available water resources decreased by $50 \%$. The mayor called for restricting irrational use of water and attributed the appearance of water scarcity on inadequate enrichment of the aquifers due to the dry winter (low rainfall and snow cover) and, predominately, to water resources mismanagement in previous years. The mayor stated that, due to the island's abundance of water, during the last 20 years much of the water supply was used to irrigate crops, which was the main cause of the observed decrease in water availability and argued that $30 \%$ of the inhabitants illegally use water resources. To mitigate water scarcity the Municipal Council took following immediate actions to: a) shut down all municipal faucets, b) sue everyone responsible for illegal use of water from the water supply network of the Municipality and, c) implement immediately the provisions of the water regulation, in particular those relating to illegal water supply, i.e. the imposition of penalties for illegal water abstraction, and the ban of water supply for irrigation from the municipal network. Similar but less severe situations faced the island in following summers. 
From this description it becomes obvious that, as result of high availability of good quality water on Samothraki, appropriate water management actions in case of droughts are not preventive and are implemented ad hoc. The same approach holds true in case of floods. The cracked groundwater aquifers are shallow with low storage capacity forcing precipitation to flow predominately overland. Thus, even during the dry season, when groundwater aquifers are nearly exhausted, rainfalls may cause disastrous flash floods. Moreover, a too high number of undernourished free grazing animals exploit and degrade pastures, thus magnifying naturally occurring soil erosion ${ }^{9}$ (Panagopoulos et al. 2019). In September 2017, an extreme flood event triggered several landslides, demolished buildings (even the Medieval Fonias tower located at the mouth o Fonias stream) and covered large parts of Chora, including the town hall, with rocks and debris. Flood forecasting infrastructure and respective precautionary measures are missing, thus only post flood remedial actions are being implemented.

Water abstraction from streams and springs do not only affect domestic water supply during particularly dry years. It additionally affects steam flow downstream abstraction points. Thus, a number of perennially or nearly perennially streams (i.e. that naturally desiccate near their outflow to the sea) may cease to flow from their outflow to several $\mathrm{km}$ upstream. As a result, the ecological integrity and quality of downstream stream reaches is threatened and estuaries receive less fresh water, thus affecting coastal habitats and limiting nutrient inputs to the sea.

The domestic water supply network covers the settlements of the island, buildings outside settlements, municipal campsites and other productive activities taking place throughout the island. However, it is in a bad condition and leakages occur frequently. In addition, it needs further expansion (Operational Program of the Municipality of Samothraki 2013-2014). The Region of Eastern Macedonia \& Thrace (2012) anticipated $1.000 .000 €$ to repair the network. However, according to the Operational Plan of Samothraki Municipality 2014-19, a 750,000,00 € project foreseen to improve the domestic water network, has been cancelled. Recently, the domestic water supply pipe between Palaeopolis and Kamariotisa has been replaced, while further improvements of the networks are anticipated by the Municipality.

Most of the traditional cement canals used for irrigation are outdated and, even if they are operational, users commonly neglect them. Nowadays, irrigation is mostly carried out with PVC pipes. Users place their own pipes to abstract water for irrigation and commonly several pipes run along the stream banks, thus negatively affecting the aesthetics of the landscape.

A WWTP for Kamariotissa has been integrated into the planning of the Municipality. The respective study has been completed and the construction of the plant is foreseen to start soon. The plant will be built on a $2,700 \mathrm{~km}^{2}$ location west of the settlement, near the Akrotiri lagoon. In its initial phase it will serve 3,000 people and in the final phase, in $2025,9,000$ people. The prolonged ventilation system was chosen as the treatment method. The treated sewage will be disposed of in the sea, SW of Akrotiri. The possibility to transfer the waste waters of Chora to the Kamariotissa WWTP is being studied. For Lakoma and Prof. Elias, the sites for the construction of a WWTP have been selected. For Lakoma, the study for the transport and disposal of wastewater has been completed, whereas a compact WWTP is anticipated to serve the needs of 1,500 inhabitants of the settlement (Eastern Macedonia \& Thrace Region 2012). Finally, regarding the Municipal campings, the location near Kardelis stream for wastewater treatment/disposal and the construction of wastewater and drainage networks inside the camping and of sewage pipelines to a WWTP have been approved.

\section{Proposed management measures}

To ensure sustainable water use on the island, an integrated Water Resources Management Plan (WRMP) should be implemented. The WRMP should consider current and future water uses and should anticipate the ecosystems requirements as well as future climate change impacts. In addition, it is necessary to connect water management aspects with the long-term socio-economical sustainability of the island (e.g. Rau et al. 2014, Petridis \& Fischer-Kowalski 2016). Institutional improvements such as the upgrade of the Water and Sewerage Office within the Department of Technical Services and Quality

\footnotetext{
${ }^{9}$ Naturally occurring erosion derives from tectonically deformed bedrock, steep slopes, and restricted groundwater aquifers creating flash floods.
} 
of Life of the Municipality, improved maintenance, and better coordination of communication would ensure the success of the WRMP.

According to our estimations the vast majority of water needs $(98.6 \%)$ comprise irrigation demands. Thus, water resources management should predominately target on irrigation water. To combat water shortages occurring during the summer period on the island, it is necessary to include within the WRMP the real current and future water needs of the island. For that purpose, it is essential, as a first basic step, to apply a monitoring system primarily targeting on water consumption (metering system) and secondarily on freshwater resources availability. Simultaneously, a long-term sustainable socioeconomic strategy should be determined, on which the WRMP should be adapted.

Irrigation systems and agricultural production should be compliant to climate change issues. Respective measures may include the replacement or repair of damaged networks for domestic supply and irrigation, exploring the possibility of selecting crop varieties requiring less water, selection of varieties that thrive off-summer, ban free supply of irrigation water, explore possibilities to irrigate with reused water, and manage/control water abstraction according to specific hydrogeological studies (Ministry of Environment \& Energy 2016). During the last years a seed mixture developed in Portugal for "sown biodiverse pastures" with a high share of legumes has been introduced to the island to serve as animal feed. The crops are less water demanding than existing pasture ${ }^{10}$. Experimental fields properly tended yielded between 20 and 50\% higher productivity than the neighboring fields (Fischer-Kowalski et al. 2019). Moreover, expanding irrigation for olive trees is not necessary when focusing not on quantity, but on quality of the harvest.

Measures concerning irrigation practices can help to save vast amounts of fresh water. Most important measure is to control illegal water abstractions from spring and streams. Today only two farmers have licenses to abstract water from streams. Thus, farmers, especially those owing large fields and use high amounts of water, should apply for licenses. Nevertheless, the total water abstracted form streams should be compliant with the demands of the WFD. Thus, the amounts of water abstracted should ensure the integrity and ecological quality of stream ecosystems. This, in turn, requires ensuring ecological (or environmental) flows (e-flows). The establishment of e-flows is ecosystem specific and requires the implementation of special studies targeting stream reaches affected by water abstraction. These studies will indicate the maximum water withdrawal to be allocated for irrigation for each stream.

All users, particularly those irrigating large land areas, should apply for water abstraction licenses. In total, the licenses for surface water abstraction should be adapted to the overall permissible water withdrawal per stream (according to the e-flows study). To control overuse, a metering system should be installed by each user. The Municipality should apply for regional funds to cover the installation of flow meters. Also, it is recommended to restore the traditional cement canal irrigation network and use PVC pipes instead only when it is absolutely necessary. The numerous PVC pipes that run parallel to the stream banks should be ban. A central PVC pipe may be placed to distribute water through smaller pipes to individual users.

As the "Xiropotamos GW system" aquifer shows signs of salinization (Romaidis \& Favas 2010), water withdrawal should be strictly controlled, and excess pumping should be avoided. Manual or automatic monitoring of groundwater levels and conductivity to control extraction is additionally recommended.

In some places, inefficient irrigation technologies are used (e.g. travelling guns involving high evaporation). Failure of the public system to supply sufficient amount of water to all users leads to illegal water abstractions or to maintenance of improvised and outdated irrigation structures. Pressures on surface and groundwater could increase in the future due to expansion of irrigation, e.g. for watering olive trees. The planned Xiropotamos reservoir would solve this problem only for part of the island.

It is a need to apply sustainable irrigation water use on the entire island. This requires knowledge on how much water in the soil profile is available to the crops and how much water the crop needs. Measuring and monitoring soil water status should be essential parts of an integrated management program. In addition, irrigation water use should strictly adapt to the plant needs and farmers should follow the recommendations of the state (e.g. Law 16/6631/89). Moreover, expert agronomists should

\footnotetext{
${ }^{10}$ According to Schoder et al. (2016), legumes used as fodder for livestock in Samothraki contribute to almost 1 $\mathrm{hm}^{3}$ of potential irrigation per year.
} 
be hired by the Municipality to advise farmers on irrigation water use according to the plant needs and the soil moisture status.

In order to increase exploitable freshwater resources in the future and cover the irrigation needs for the whole island, it is recommended to explore the possibility, instead of reservoir constructions, to store winter and spring stream flows into groundwater aquifers (natural enrichment of groundwater aquifers) or in underground reservoirs. It is easy then to exploit the stored water with shallow wells. Through this method evaporation losses will be minimized. This solution is preferred compared to the installation of new drillings. It is less energy demanding and will protect groundwater aquifers from future salinization. A geological/ geotechnical study may indicate appropriate areas in terms of dimensions, grain size characteristics of the aquifers and storage volumes.

However, new drillings do not have to be completely excluded if appropriately designed. With an improved well system, distributed reasonably over the island and constructed for the total irrigation demand, several advantages can be expected, including easier coordination, better spatial distribution (shorter pipe network), as well as minimal evaporation losses and impact on stream flows. Going for an extended groundwater exploitation, the positioning of wells has to be considered very carefully and further research including an updated hydrogeological study should be carried out, in order to protect groundwater aquifers from salinization (Schoder et al. 2016).

Considering domestic water supply, Romaidis (2003) proposes that waters of best quality should be allocated for drinking purposes. Thus, springs still exploited for irrigation purposes should be exclusively allocated for domestic use, since their supply is sufficient for that purpose. Only excess water should be used for irrigation. There is a need to cover all water needs for domestic purposes from springs and skip drillings. For example, the aquifer supplying Kamariotissa is probably contaminated by irrigation return flows and domestic waste waters from permeable cesspits as the high concentrations of nitrate and ammonia indicate. It is thus necessary to skip this drilling and target spring or stream water to cover domestic needs of that settlement.

Regarding qualitative issues, the vast majority of springs present excellent characteristics and can be used for drinking purposes and bottling. Even stream water may be used for drinking purposes after primarily treatment (settling, filtration and disinfection) to combat any microbial pollution, that may derive from e.g. dead animals. Incidents of domestic water microbial pollution may appear as a result of damaged water distribution systems that may be affected by permeable septic tank inflows.

The existence of protection zones around water abstraction points that serve domestic water supply is necessary for the protection of public health. These protection zones are designated in accordance with the provisions of the law, i.e. the law 1650/86 for the environment and the regulations for the management of water resources (Ministerial Decision 51/2007 and law 3199/03) and the RBMPs. However, such zones are missing in Samothraki and it is needed to be established. These zones should be fenced in order to protect them from any human activity and keep free grazing animals away. Any households in the vicinity of these zones should strictly use impermeable septic tanks, while owners of fields surrounding these zones should avoid applying agrochemicals.

In order to establish high quality for domestic water supply with minimum costs and risks and avoid leakages, the existing old pipe network should be repaired and/or replaced. A monitoring (metering) system for all water reservoirs used for domestic supply and for all water users should be installed. Finally, the quality of all water abstraction points for domestic use, i.e. springs, cisterns, wells and drillings, should be secured by establishing protection zones.

To control flood hazards, a flood early warning system is required. HCMR recently installed a meteorological station at Koufouklio and an automatic water level recorder at Fonias stream outflow. Using the weather forecasting data in combination with the recordings of local rainfalls and stream water levels it is possible to develop a flood early warning system that will be used by the Municipality to take appropriate measures in advance.

To control erosion, the number of free grazing animals should be reduced, and grazing has to be managed sustainably by establishing spatially and temporally controlled grazing areas. However, a really effective erosion mitigation plan would additionally require reforestation to the greatest possible extent along with protection against wildfires, as well as constructive practices, e.g. building of terraces. 
The latter could prevent soil loss if applied in the hilly vulnerable areas by increasing the retention of soil resources in the upland catchments. At the areas where farming is practiced, the newly introduced Sown Biodiverse Permanent Pastures may act toward both controlled grazing and soil erosion abatement (Panagopoulos et al. 2019).

Finally, education and awareness raising for all water users (e.g. farmers, tourists, school children) would be a step towards more efficient water usage.

\subsubsection{Conclusions}

\section{Current situation}

- Samothraki has more than adequate water resources; the total annual available water resources $\left(\sim 76.21 \mathrm{hm}^{3}\right)$ exceed by around 5 times the total annual water demands $\left(\sim 15.65 \mathrm{hm}^{3}\right)$.

- Registered water uses $\left(1.76 \mathrm{hm}^{3}\right)$ are by far less than the estimated real water demands $(15.65$ $\mathrm{hm}^{3}$ on the average). The difference is mainly covered by illegal surface water abstraction for irrigation (either from streams or springs).

- As a result of illegal water abstractions and inadequate management, despite high water availability, water shortages may occur during the summer period, even for domestic consumption. In lack of a long-term water resources management strategy in combination with the availability of freshwater resources on the island, respective management actions are implemented ad hoc.

- Water abstraction from streams and springs do not only affect domestic water supply during particularly dry years. It additionally substantially affects steam flow, turning particular stream reaches from perennial to temporary, with adverse effects on their ecological quality and integrity.

- Due to the nature of the cracked groundwater aquifers, the island is prone to flash floods. Flood forecasting infrastructure and respective precautionary measures are missing, thus only post flood remedial actions are being implemented.

- As a result of natural factors (tectonically deformed bedrock, steep slopes, and restricted groundwater aquifers) and a disproportionate number of free grazing small ruminants, erosion rates on the island are immense.

- Parts of the domestic water supply network are suffering from leaks, causing water losses and occasional microbial contamination, and need to be repaired or replaced.

- The traditional cement irrigation networks are largely destroyed, and irrigation takes place using PVC pipes.

- The groundwater aquifer of the drilling used to supply domestic water to Kamariotissa is polluted, as the high concentration of nitrate and ammonia indicate.

\section{Proposed water management measures}

- To ensure sustainable water use on the island, a long-term integrated Water Resources Management Plan (WRMP) should be implemented, including socio-economical sustainability aspects, aquatic ecosystems' requirements, and future climate change impacts.

- Irrigation systems and agricultural production should be compliant to climate change issues. It is recommended to select less water demanding crop varieties (e.g. "sown biodiverse pastures"), and varieties that thrive off-summer. To ensure high quality of olive oil produced it is recommended not to irrigate olive groves.

- In the WRMP, the stream ecosystems' summer water requirements should be integrated and maximum withdrawal for each stream should be estimated.

- All users, particularly those irrigating large land areas, should apply for water abstraction licenses.

- The number of licenses for surface water abstraction should be adapted to the overall permissible water withdrawal per stream (according to a e-flows study). To control water overuse, a metering system should be installed by each user. The Municipality should apply for regional funds to cover the installation of flow meters.

- It is recommended to restore the traditional cement canal irrigation network and use PVC pipes only when it is absolutely necessary. The numerous PVC pipes that run parallel should be 
banned. A central PVC pipe may be placed to distribute water through smaller pipes to individual users.

- Inefficient irrigation technologies, such as travelling guns, should be banned.

- An irrigation scheme within the WRMB should be based on soil moisture and the real water needs per crop type. This requires soil moisture monitoring and agronomical know how that should be provided by the upgraded Water \& Sewage Office of the Municipality.

- To avoid salinization of the "Xiropotamos GW system", it is recommended to regularly monitor water level and conductivity of drillings and adapt water abstraction accordingly. These actions should also be arranged by the Water \& Sewage Office of the Municipality.

- New drillings do not have to be excluded if appropriately designed. An improved well system distributed reasonably over the island and constructed for the total irrigation demand offers several advantages. In this frame, the positioning of wells has to be considered very carefully and further research including an updated hydrogeological study should be carried out, in order to protect groundwater aquifers from salinization.

- In order to increase exploitable freshwater resources in the future, it is recommended, instead of reservoir constructions and opening of new drillings, to explore the possibility to store winter and spring flows underground, if this agrees with the results of geological/geotechnical studies.

- To avoid leakages and contamination, the domestic water supply network should be repaired or replaced, where needed.

- A monitoring (metering) system for all water reservoirs used for domestic supply and for all water users should be installed.

- Domestic water demands should be covered by springs and domestic water use from drillings should be skipped. Spring use for irrigation should be banned, and only excess water should be used for irrigation. It is recommended to shift water demands of Kamariotissa from ground water to spring or stream water. Stream water may be used for drinking purposes after primarily treatment to avoid microbial pollution.

- Protection zones around water abstraction points should be established to secure an excellent drinking water quality and minimize chlorination.

- An early warning system for catastrophic rain events and flash floods should be developed and applied.

- To combat erosion, there is an urgent need to drastically reduce free grazing animals, manage grazing sustainably by establishing spatially and temporally controlled grazing areas, assist forest regeneration, perform reforestations, and build terraces on hilly vulnerable areas to prevent soil loss. The newly introduced "sown biodiverse pastures" may act toward both controlled grazing and soil erosion abatement. 


\subsubsection{References}

Anthitsa V. N., K.V. Arsenopoulos, V. Bampidis (2017). The quantitative and qualitative water requirements of livestock - Part 2. The quantities of water consumed by different species and categories of animals (in Greek). Project: Water and Farm Animals.https://www.researchgate.net/publication/ 324706548 Oi anankes se posoteta kai poioteta nerou gia ta paragogika zoa Meros 2 Oi posotet es_katanaloses nerou apo ta diaphora_eide_kai_kategories_zoon_In_Greek (in Greek).

Gatziou M., M. Andreadaki,. M. Tsalkatidou (2006). Water demands and rates policy in provincial cities in Greece. European water 15/16: 33-44.

Koustogiannis D., A. Andreadakis, et al. (2008). Assistance of the Central Water Service for "Setting up a mid-term Program for the Protection and Management of the Country's Freshwater Potential". National Program for the Management and Protection of Water Resources, Volume I, Volume II, Ministry of Environment Spatial Planning and Public Works, Central Water Service (in Greek).

NoSI (2011). Identification report for Samothraki. Network of Sustainable Islands "Dafne"(in Greek).

Panagopoulos Y., E. Dimitriou, N. Skoulikidis (2019). Vulnerability of a Northeast Mediterranean Island to Soil Loss. Can Grazing Management Mitigate Erosion? Water 11, 1491; doi:10.3390/w11071491.

River Basin Management Plan (RBMP) of the Thrace River Basin District (2013). Annex A10: Assessment and Classification of the Qualitative (Chemical) and Quantitative Status of Ground Water Systems. Ministry of Environment \& Energy, Special Secretariat for Water, September 2013 (in Greek).

River Basin Management Plan (RBMP) of Thrace Hydrological District (2013). Drawing of Management Plans in East Macedonia \& Thrace in Accordance with the Requirements of Directive 60/2000/EC, according to Law 3199/2003 and the Ministerial Decision 51/2007. Intermediate Phase 2 Aquatic Apartment of Thrace. Management Plan of Thrace Water District, January 2013 (in Greek).

River Basin Management Plan (RBMP) of Thrace Hydrological District (2017). 1st Review of the River Basin Management Plan. District of Thrace (EL12). Strategic Environmental Impact Study. Deliverable: P.18, Special Secretariat for Waters. Ministry for Environment \& Energy, September 2017 (in Greek).

Romaidis I. (2003). Hydrogeological identification studyfor the Municipality of Samothraki. Technical report IGME, Xanthi (in Greek).

Romaidis I. (2006). Hydrogeological study of Samothraki springs. Malamatina. IGME. Xanthi (in Greek).

Romaidis I., N. Favas (2010). Hydrogeological study. Water District of Thraki. IGME (in Greek).

Skoulikidis N., A. Lampou, I. Karaouzas, K. Gritzalis, M. Lazaridou, S. Zogaris (2014). Stream ecological assessment on an Aegean island: insights from an exploratory application on Samothraki (Greece). Fresenius Environmental Bulletin. 23(5). 1173-1182.

Skoulikids N., A. Lampou, S. Laschou (2019). Unraveling aquatic quality controls of a nearly undisturbed Mediterranean Island. Water (under submission).

Vardoulakis M. (2011). Environmental Impact Assessment for the Xeropotamos reservoir, in Samothaki Island. Technical Report, Ministry of Agriculture (in Greek). 


\subsection{Contribution to an effective Natura 2000/MAB management}

The main obstacle that remains for the official designation of Samothraki as a Biosphere Reserve is the lack of national legislation regarding the Natura 2000 areas of the island (and future BR core zones). Three quarters of the terrestrial area of Samothraki and $50 \mathrm{~km}^{2}$ of the adjoining marine area have been protected under EU's 92/43 EEC Habitats Directive (Dimopoulos et al. 2005), but only now the Greek Ministry of Environment is undertaking the final legal steps and discusses future management. These areas are of great value for nature conservation and for the island's future as a tourist destination. The partial lack of awareness and recognition of these values by the local population may undermine conservation efforts. While the Greek government is trying to find nationwide solutions for all Natura 2000 areas, the vice mayor of Samothraki has been trying to solve this issue independently, in advance of a national law that is missing. We aimed at accelerating this process, and gave support to the Municipality in defining a local plan for Natura 2000, finding ways to link the management of Natura 2000 and BR core areas, essentially striving for a "bottom up" local agreement that can then be proposed to the higher authorities. One of the project's central aims was to enable a continuation of the conservation efforts while the national decision on the management of the Natura 2000 area was pending. We aimed at further contributing to the sensitization of the local population towards proper protection of Natura 2000 areas, reinforcing local public awareness of the need of biodiversity conservation and generating support for this. Two actions were planned in this respect:

- The use of camera traps for raising awareness on the conservation status of designated areas: Despite its successful launch, this action had to be cancelled due to legal issues with the military. We collected some interesting footage but could not use it in any way.

- Tree sampling to (i) reconstruct forest structure as a "mirror" of past land use practices, and (ii) identify critical priority areas that require immediate protection and may guide forest regeneration projects: Field research for this working package was conducted in 2017. The goal was to sample areas of ancient oak forest in different mountain areas, establish the age distribution of the trees and regrowth patterns. This allowed, on the one hand, reconstructing past land use patterns (in particular charcoal production and wood pasture), on the other hand it provided estimates of risk for forest die out. Local citizens (approximately 20 of various age groups and professional backgrounds) participated with great enthusiasm - for many it was a unique and very important experience. In personal conversations participants told us that they have seen the island from an unknown perspective and had not been aware of its natural assets. Based on the data collected, Carina Heiling completed her master's thesis in Forestry and is currently preparing a publication in a peer reviewed journal (Heiling et al. forthcoming).

\subsection{Video documentary}

A film team accompanied the research team since 2015 and collected rich footage of the research process, but also of matters surrounding local living conditions, people's perceptions and potentials for a sustainability transformation of the island. The film is completed and was shown for the first time during the summer school 2018. It had its official premiere on 18. October 2018 at the Filmcasino in Vienna. The screening was well attended and well rerceived. The film has also been shown during an event organized by the "Verein für griechisch-österreichische Freundschaft" to the honour or the visiting Greek State Secretary for digital communication, and to the students of Social Ecology at the institute in January 2018.

The film can be watched online since August 2019:

https://www.youtube.com/watch?v=S3SzFfiYIXM\&feature=youtu.be

\subsection{Summer schools 2018 and 2019}

\section{Summer School 2018}

For the $5^{\text {th }}$ time, a student excursion was conducted on Samothraki. In collaboration with HCMR, 16 international students were trained in socioecological and aquatic science methods. The course was designed as a ten-day excursion with the aim to learn and apply aquatic ecology and social ecology approaches in a local setting while supporting current research and building synergy with the UNESCO 
Biosphere Reserve process. The course gave students the opportunity to engage in a real-life project and utilize their scientific training to support the process further, namely the creation of a management plan with a set of activities towards sustainability, and a science plan for further research on the island that would also meet local interests. The summer school provided students the experience of participating in a transdisciplinary research process, being exposed to a search for solutions for sustainability and development challenges and learning to interact with stakeholders in a culturally challenging environment. Students' reports were published as a working paper (Fischer-Kowalski and Petridis 2019).

\section{Summer School 2019}

The $6^{\text {th }}$ Samothraki Summer School was again held in collaboration with HCMR and trained 25 international students on aquatic and socioecological methods. The course was designed as a ten-day excursion focusing on tourism, waste, water metabolism (water management) and agriculture. The students' reports will be published as a working paper in 2020 .

\subsection{Deliverables}

\subsubsection{Webpage}

A working contract was made with Jacqueline Kirby, local inhabitant on Samothraki, for the duration of the project, to regularly update and maintenance of the project webpage (www.sustainablesamothraki.net). The webpage serves as communication platform and is part of a broader outreach strategy; it gains in importance. Currently, the webpage is visited annually by 8.700 different users with 44,000 page views.

\subsubsection{Scientific Presentations}

Noll, Dominik, Dominik Wiedenhofer, Marina Fischer-Kowalski. 2019. The role of science in the sustainability transition of agriculture: A case study from Samothraki, Greece. XVII European Rural Development Network Conference: CAP 2021+: balanced development among the dimensions of rural sustainability. September 24-26. Velké Bílovice, Czech Republic.

Noll, Dominik, Dominik Wiedenhofer, Marina Fischer-Kowalski. 2019. The Island Samothraki As A Real-World Lab For Sustainable Livestock Farming. NEST Conference: Transitions to where? Shared values and visions for sustainability transitions. April 4-5. Lisbon, Portugal.

Fischer-Kowalski, Marina. 2019. How science supports a sustainability transition on Samothraki. Samothraki Open Forum 2019 "Sustainable Growth through Synergies". Samothraki, June 29, 2019

Noll, Dominik, Dominik Wiedenhofer, Alessio Miatto, Simron Singh. 2018. Infrastructure expansion, waste generation and EU policies on Circular Economy in Samothraki, Greece: An island's dilemma. Science to support circular economy symposium of the Christian Doppler Laboratory for Anthropogenic Resources. September 19. Vienna, Austria.

Fischer-Kowalski, Marina. 2018. Social Ecology: Research for a Sustainable Future. Social Ecology Symposium as part of the "Be Open - Science and Society Festival" organized by the FWF. September 10. Vienna, Austria.

Petridis, Panos, Marina Fischer-Kowalski. 2018. The role of transdisciplinary socioecological research in facilitating the sustainability transition of an island. XV Congress of the International Society for Ecological Economics 2018: "Ecological Economics and Socio-ecological Movements: Science, policy and challenges to global processes in a troubled world". September, 10-12. Puebla, Mexico.

Noll, Dominik. 2018. Samothraki's metabolism - stock modelling as a path towards adequate accounts. Social Ecology Research Seminar. Institute of Social Ecology, University of Natural Resources and Life Sciences (BOKU). January 24. Vienna, Austria 
Noll, Dominik, Tamara Fetzel, Panagiotis Petridis, Marina Fischer-Kowalski. 2017. Achieving sustainable small ruminant farming on Samothraki. 6th International Symposium for Research in Protected Areas. University of Salzburg. November 2-3. Austria.

Fischer-Kowalski, Marina, Panagiotis Petridis, Dominik Noll. 2017. Guiding a sustainability transition on the Greek island of Samothraki: An experience in transdisciplinarity. Workshop on Governance, Institutions and Resource Use on Small Islands: Developing A Conceptual Framework. October 23. Waterloo, Canada.

Petridis, Panos. 2017. Degrowth as the central political project of the Commons. Commons Festival. September 7. Athens, Greece

Petridis, Panos, Marina Fischer-Kowalski. 2017. Using research to facilitate a sustainability transformation of a Greek island. Transformations 2017 Conference: Transformations in Practice. September 1. University of Dundee, UK

\subsubsection{Scientific Publications}

Fischer-Kowalski, Marina, Markus Löw, Dominik Noll, Panos Petridis and Nikolaos Skoulikidis. 2020. Samothraki in transition: A report on a multi-years real world lab to promote the sustainability of a Greek island. Submitted to: Sustainability special issue - The Metabolism of Islands. Simron Singh, Marina Fischer-Kowalski, Marian Chertow (eds.).

Noll, Dominik, Christian Lauk, Veronika Gaube, Dominik Wiedenhofer. 2020. Small ruminant farming on the Greek island Samothraki caught in a deadlock. The importance of regional contexts for effective EU agricultural policies. In preparation for: Sustainability special issue - The Metabolism of Islands. Simron Singh, Marina Fischer-Kowalski, Marian Chertow (eds.).

Panagopoulos, Y., Dimitriou, E., Skoulikidis, N., 2019. Vulnerability of a Northeast Mediterranean Island to Soil Loss. Can Grazing Management Mitigate Erosion? Water 11, 1491. https://doi.org/10.3390/w11071491

Noll, D., Wiedenhofer, D., Miatto, A., Singh, S.J., 2019. The expansion of the built environment, waste generation and EU recycling targets on Samothraki, Greece: An island's dilemma. Resources, Conservation and Recycling 150, 104405. https://doi.org/10.1016/j.resconrec.2019.104405

Fischer-Kowalski and Panos Petridis (ed.). 2019. 5th Summer School on "Aquatic and Social Ecology" on Samothraki, Greece. Social Ecology Working Paper 178. Available online: (accessed 23.10.2019).

https://boku.ac.at/fileadmin/data/H03000/H73000/H73700/Publikationen/Working_Papers/WP1 78_Web_PDFA.pdf

Fetzel, Tamara, Panos Petridis, Dominik Noll, Simron Jit Singh, and Marina Fischer-Kowalski. 2018. "Reaching a Socio-Ecological Tipping Point: Overgrazing on the Greek Island of Samothraki and the Role of European Agricultural Policies." Land Use Policy 76 (July): 21-28. https://doi.org/10.1016/j.landusepol.2018.04.042.

Petridis, Panos, Marina Fischer-Kowalski, Simron J. Singh and Dominik Noll. 2017. The role of science in sustainability transitions: citizen science, transformative research, and experiences from Samothraki island, Greece. Island Studies Journal, 12(1): 115-134.

Petridis, Panos and Julia Huber. 2017. A Socio-metabolic Transition of Diets on a Greek Island: Evidence of "Quiet Sustainability". In: "Socio-Metabolic Perspectives on the Sustainability of Local Food Systems". E. Fraňková, W. Haas, S.J. Singh (eds.). Springer, 263-289.

\subsubsection{Academic qualifications}

Petridis, Panos. 2017. The Role of Science in Sustainability Transitions. Lessons from Transdisciplinary Socioecological Research on a Greek Island. PhD Thesis in Social Ecology, Alpen Adria University.

Schwaiger, Nathalie. 2017. Exploring Sustainable Tourism on Samothraki. Current State and Perspectives. Master thesis in Social Ecology, Alpen Adria University. 
Lange, Olivia. 2017. Gesundheitsversorgung auf der griechischen Insel Samothraki. Problemlagen und Beitzräge zu einem nachhaltigen Entwicklungspfad. Master thesis in Social Ecology. Alpen Adria University.

Löw, Markus. 2017. Spatial Patterns of Land Cover Dynamics on Samothraki Island, Applying Remote Sensing on complex Mediterranean Pastures. Master's Thesis. Alpen Adria University.

Fetzel, Tamara. 2018. Feeding the world from grass. Dissertation (Dr.rer.nat), Alpen Adria University.

Heiling, Carina. 2018. Spuren historischer Ressourcennutzung anhand dendrologischer Befunde: Eichenwälder auf der Insel Samothraki. Master Thesis in Forest Ecology at BOKU, Vienna.

Baierl, Christopher. 2019. Analysis of EU-Common Agriculatural Policy subsidies on the Greek Island of Samothraki. Master thesis in Social Ecology, Alpen Adria University

\section{Acknowledgements}

The authors gratefully acknowledge funding from the Austrian National Committee for UNESCO's "Man and the Biosphere Programme" at the Austrian Academy of Sciences (OEAW). We wish to thank Giorgos Maskalidis, Carlota Marañon, Jacqueline Kirby, Panos Petridis, Evgenia Tsianou and all participants of the summer schools 2012, 2014, 2016, 2017 and 2019 for their assistance during data collection and many fruitful discussions. We also thank the former head of the Technical Service Department of the Municipality, Parthena Romanidou, who assisted our efforts regarding both the desk study and provided us vehicle and drivers (Trymphon Katsikis and Nikos Koutsouris) for the field survey, Yiannis Koletsas for providing information on water management, Mirsini Papanikolaou, Stavros Chondros and Doukas Chailas for providing us data. We thank the Hellenic Statistical Authority (ELSTAT) for the provision of data and continuous assistance. Further we want to thank Prof. Marina Fischer-Kowalski for her advice and provision of required resources for conducting this study. We finally thank the former Mayor of the Municipality of Samothraki, Athanasios Vitsas, for productive discussions on water management issues. 


\section{Appendix I}

\section{CALCULATION OF THE ISLAND'S CROP IRRIGATION REQUIREMENTS}

\section{Table 1}

Categories of Samothraki crops according to Law 16/6631/89 and irrigated area (in acres) according to data of the Municipality for 2017

\begin{tabular}{|l|l|l|l|l|l|}
\hline \multicolumn{6}{|c|}{ Crop type categories } \\
\hline I & II & III & IV & V & VI \\
\hline
\end{tabular}

\begin{tabular}{|c|c|c|c|c|c|c|c|}
\hline Cultivation & $\begin{array}{c}\text { Irrigated } \\
\text { area } \\
\text { (acres) }\end{array}$ & Cultivation & $\begin{array}{c}\text { Irrigated } \\
\text { area } \\
\text { (acres) }\end{array}$ & Cultivation & $\begin{array}{c}\text { Irrigated } \\
\text { area } \\
\text { (acres) }\end{array}$ & Cultivation & $\begin{array}{c}\text { Irrigated } \\
\text { area } \\
\text { (acres) }\end{array}$ \\
\hline wine yards & 115 & pear/peach trees & 200 & garlic (dry) & 15 & wheat (soft) & 1312 \\
\hline olive groves & 9000 & broad beans (green) & 75 & tomatoes (industrial) & 25 & wheat (hard) & 351 \\
\hline barley for hay & 3019 & watermelons & 145 & tomatoes & 210 & barley & 2953 \\
\hline vetch for hay & 1976 & melons & 65 & tomatoes (greenhouse) & 1 & corn & 315 \\
\hline alfalfa (perennial) & 262 & cauliflowers & 2 & beans (green) & 100 & sorghum (animal feed) & 7 \\
\hline dry grass (perennial) & 200 & spinach & 62 & pumpkins & 30 & barley (grazing) & 2300 \\
\hline meadows* (animal feed) & 124 & leeks & 3 & cucumbers & 25 & sunflowers & 14 \\
\hline beens & 270 & onions (green) & 2 & cucumbers (greenhouse) & 1 & artificial pastures/meadows (animal feed) & 101 \\
\hline broad beans (animal feed) & 264 & onions (dry) & 65 & aubergines & 30 & \multirow{2}{*}{ Total irrigated area (acres) } & \multirow{2}{*}{29,664} \\
\hline tree farming & 6000 & garlic (green) & 2 & peppers (green) & 23 & & \\
\hline
\end{tabular}




\section{Table 2}

Irrigation requirements for the different crop types in Samothraki Island according to Law 16/6631/89 (data are particularly for the Thrace Hydrological District)

\begin{tabular}{|c|c|c|c|c|c|c|c|c|}
\hline \multicolumn{7}{|c|}{ Irrigation needs in $\mathrm{m}^{3}$ /acre for Thrace Hydrological District (Common Ministerial Decision 16/6631/89) } \\
\hline Crop category & \multicolumn{2}{|c|}{ June } & \multicolumn{2}{c|}{ July } & \multicolumn{2}{c|}{ August } & \multicolumn{2}{c|}{ September } \\
\hline & $\min$ & $\max$ & $\min$ & $\max$ & $\min$ & $\max$ & $\min$ & $\max$ \\
\hline I & 82 & 102 & 96 & 115 & 91 & 110 & 63 & 80 \\
\hline II & 90 & 111 & 105 & 126 & 99 & 120 & 69 & 87 \\
\hline III & 98 & 120 & 114 & 136 & 107 & 130 & 75 & 94 \\
\hline IV & 105 & 129 & 122 & 147 & 115 & 140 & 80 & 101 \\
\hline V & 112 & 139 & 131 & 157 & 124 & 150 & 86 & 109 \\
\hline VI & 120 & 148 & 140 & 168 & 132 & 160 & 92 & 116 \\
\hline
\end{tabular}

\section{Table 3}

Irrigation requirements for the different crop types in Samothraki Island considering an average irrigation type efficiency of $85 \%$ (mixture of surface distribution, sprinkler and drip irrigation) according to Law 16/6631/89

\begin{tabular}{|c|c|c|c|c|c|c|c|c|}
\hline \multicolumn{8}{|c|}{ Irrigation needs in $\mathrm{m}^{3} /$ acre considering the irrigation type efficiency } \\
\hline Crop category & \multicolumn{2}{|c|}{ June } & \multicolumn{2}{|c|}{ July } & \multicolumn{2}{c|}{ August } & \multicolumn{2}{c|}{ September } \\
\hline & $\min$ & $\max$ & $\min$ & $\max$ & $\min$ & $\max$ & $\min$ & $\max$ \\
\hline I & 96 & 120 & 113 & 135 & 107 & 129 & 74 & 94 \\
\hline II & 106 & 131 & 124 & 148 & 116 & 141 & 81 & 102 \\
\hline III & 115 & 141 & 134 & 160 & 126 & 153 & 88 & 111 \\
\hline IV & 124 & 152 & 144 & 173 & 135 & 165 & 94 & 119 \\
\hline V & 132 & 164 & 154 & 185 & 146 & 176 & 101 & 128 \\
\hline VI & 141 & 174 & 165 & 198 & 155 & 188 & 108 & 136 \\
\hline
\end{tabular}




\section{Table 4}

Irrigation needs considering the irrigation type efficiency and the irrigation losses due to the water distribution system applied on the island.

\begin{tabular}{|c|c|c|c|c|c|c|c|c|}
\hline \multicolumn{7}{|c|}{ Irrigation needs in m3/acr considering the irrigation type efficiency and the irrigation losses due to the water } \\
\hline \multirow{2}{*}{ Crop category } & \multicolumn{2}{|c|}{ June } & \multicolumn{2}{c|}{ July } & \multicolumn{2}{c|}{ August } & \multicolumn{2}{c|}{ September } \\
\cline { 2 - 11 } & $\min$ & $\max$ & $\min$ & $\max$ & $\min$ & $\max$ & $\min$ & $\max$ \\
\hline I & 101 & 124 & 117 & 140 & 111 & 134 & 78 & 98 \\
\hline II & 110 & 135 & 128 & 153 & 121 & 145 & 85 & 107 \\
\hline III & 120 & 145 & 138 & 164 & 130 & 157 & 93 & 115 \\
\hline IV & 128 & 156 & 148 & 177 & 140 & 169 & 98 & 123 \\
\hline V & 136 & 168 & 158 & 189 & 150 & 181 & 105 & 133 \\
\hline VI & 145 & 178 & 169 & 202 & 160 & 193 & 113 & 141 \\
\hline
\end{tabular}

Irrigation losses are $5 \%$ for pipes and 10\% for open irrigation channels (Common Ministerial Decision 16/6631/89). We assumed that $75 \%$ of irrigation on the island is carried out by using pipes. Thus, the irrigation losses were estimated at $6.25 \%$

\section{Table 5}

Irrigation requirements of Samothraki Island for the different crop categories in $\mathrm{m}^{3}$, considering their surface area

\begin{tabular}{|c|c|c|c|c|c|c|c|c|c|}
\hline \multicolumn{8}{|c|}{ Irrigation needs considering Table 6A results and the area of the different crop categories (in $\mathrm{m}^{3}$ per crop category) } \\
\hline Crop category & \multicolumn{2}{|c|}{ June } & \multicolumn{2}{c|}{ July } & \multicolumn{2}{c|}{ August } & \multicolumn{2}{c|}{ September } \\
\hline & $\min$ & $\max$ & $\min$ & $\max$ & $\min$ & $\max$ & $\min$ & $\max$ \\
\hline I & 918638 & 1133108 & 1068767 & 1272514 & 1015150 & 1218897 & 714891 & 897191 \\
\hline II & 614997 & 752881 & 713486 & 851369 & 674090 & 811974 & 477114 & 595300 \\
\hline III & 814401 & 990634 & 942571 & 1118804 & 886497 & 1070740 & 630158 & 782359 \\
\hline
\end{tabular}




\begin{tabular}{|c|c|c|c|c|c|c|c|c|}
\hline IV & 103041 & 125798 & 119161 & 142866 & 112523 & 136229 & 79335 & 99248 \\
\hline $\mathrm{V}$ & 984927 & 1214840 & 1146717 & 1368115 & 1087110 & 1308508 & 763529 & 959381 \\
\hline VI & 16731 & 20519 & 19437 & 23225 & 18355 & 22143 & 12943 & 16190 \\
\hline
\end{tabular}

Table 6

Annual water needs (min-max) of Samothraki crops, listed per crop category

\begin{tabular}{|c|c|r|}
\hline \multirow{2}{*}{ Crop category } & \multicolumn{2}{|c|}{ Annual water needs in $\mathrm{m}^{3}$} \\
\hline & $\min$ & \multicolumn{1}{c|}{$\max$} \\
\hline I & $3,717,446$ & $4,521,710$ \\
\hline II & $2,479,688$ & $3,011,524$ \\
\hline III & $3,273,627$ & $3,962,538$ \\
\hline IV & 414,059 & 504,141 \\
\hline V & $3,982,284$ & $4,850,844$ \\
\hline VI & 67,466 & 82,078 \\
\hline TOTAL & $\mathbf{1 3 , 9 3 4 , 5 6 9}$ & $\mathbf{1 6 , 9 3 2 , 8 3 5}$ \\
\hline
\end{tabular}

5. Appendix II

HYDROCHEMICAL PROPERTIES OF SPRINGS EXAMINED BY HCMR (May 2014)

\begin{tabular}{|c|c|c|c|c|c|c|c|c|c|c|c|c|c|c|c|c|c|c|c|}
\hline $\mathrm{A} / \mathrm{A}$ & $\begin{array}{c}\mathrm{T} \\
(\mathrm{oC}) \\
\end{array}$ & $\mathrm{pH}$ & $\begin{array}{c}\mathrm{C} \\
(\mu \mathrm{s} / \mathrm{cm}) \\
\end{array}$ & $\begin{array}{c}\text { DO } \\
(\mathrm{mg} / \mathrm{l})\end{array}$ & $\begin{array}{c}\mathrm{Ca} \\
(\mathrm{mg} / \mathrm{l})\end{array}$ & $\begin{array}{c}\mathrm{Mg} \\
(\mathrm{mg} / \mathrm{l})\end{array}$ & $\begin{array}{c}\mathrm{Na} \\
(\mathrm{mg} / \mathrm{l})\end{array}$ & $\begin{array}{c}\mathrm{K} \\
(\mathrm{mg} / \mathrm{l})\end{array}$ & $\begin{array}{l}\mathrm{HCO}_{3} \\
(\mathrm{mg} / \mathrm{l}) \\
\end{array}$ & $\begin{array}{c}\mathrm{SO}_{4} \\
(\mathrm{mg} / \mathrm{l})\end{array}$ & $\begin{array}{c}\mathrm{Cl} \\
(\mathrm{mg} / \mathrm{l})\end{array}$ & $\begin{array}{c}\mathrm{SiO}_{2} \\
(\mathrm{mg} / \mathrm{l})\end{array}$ & $\begin{array}{c}\text { TDS } \\
(\mathrm{mg} / \mathrm{l})\end{array}$ & $\begin{array}{c}\mathrm{N}-\mathrm{NO}_{3} \\
(\mathrm{mg} / \mathrm{l}) \\
\end{array}$ & $\begin{array}{c}\mathrm{N}-\mathrm{NO}_{2} \\
(\mathrm{mg} / \mathrm{l}) \\
\end{array}$ & $\begin{array}{c}\mathrm{N}-\mathrm{NH}_{4} \\
(\mathrm{mg} / \mathrm{l}) \\
\end{array}$ & $\begin{array}{l}\mathrm{P}-\mathrm{PO}_{4} \\
(\mathrm{mg} / \mathrm{l})\end{array}$ & $\begin{array}{c}\mathrm{TP} \\
(\mathrm{mg} / \mathrm{l}) \\
\end{array}$ & $\begin{array}{c}\mathrm{TH} \\
\left(\mathrm{mg} / \mathrm{ICaCO}_{3}\right)\end{array}$ \\
\hline $1 \mathrm{~S}$ & 15 & 6.85 & 233 & 8 & 39.97 & 4.91 & 8.48 & 0.46 & 124.93 & 11.92 & 11.23 & 11.18 & 213.08 & 1.696 & 0.002 & 0.019 & 0.005 & 0.014 & 119.92 \\
\hline $2 \mathrm{~S}$ & 16.8 & 8.6 & 110 & 7.7 & 34.60 & 5.07 & 8.67 & 0.36 & 110.90 & 12.45 & 11.05 & 10.94 & 194.04 & 1.680 & 0.003 & 0.005 & 0.006 & 0.016 & 107.18 \\
\hline $3 \mathrm{~S}$ & 15.5 & 8.44 & 262 & 8.24 & 44.29 & 3.29 & 8.28 & 0.42 & 135.05 & 9.33 & 13.71 & 9.24 & 223.61 & 2.226 & 0.002 & 0.016 & 0.005 & 0.005 & 124.04 \\
\hline $4 \mathrm{~S}$ & 16.4 & 9.11 & 222 & 4.95 & 33.38 & 3.47 & 89.65 & 11.54 & 96.26 & 15.96 & 140.66 & 11.23 & 402.15 & 1.673 & 0.002 & 0.012 & 0.029 & 0.038 & 97.56 \\
\hline
\end{tabular}




\begin{tabular}{|c|c|c|c|c|c|c|c|c|c|c|c|c|c|c|c|c|c|c|c|}
\hline $5 \mathrm{~S}$ & 16.7 & 8.28 & 267 & 7.2 & 36.47 & 6.35 & 10.24 & 0.47 & 122.49 & 15.12 & 14.6 & 15.12 & 220.86 & 1.208 & 0.002 & 0.022 & 0.005 & 0.005 & 117.11 \\
\hline $6 \mathrm{~S}$ & 41.8 & 6.63 & 19000 & 2.1 & 768.41 & 76.61 & 3538.2 & 478.3 & 408.46 & 77.37 & 4385 & 74.4 & 9806.65 & 0.045 & 0.002 & 8.042 & 0.029 & 0.032 & 2232.30 \\
\hline $7 \mathrm{~S}$ & 42.8 & 6.62 & 17000 & 4.9 & 645.96 & 37.25 & 4042.1 & 553 & 405.77 & 23.87 & 4299 & 87.6 & 10094.75 & 0.045 & 0.002 & 7.117 & 0.026 & 0.029 & 1764.89 \\
\hline $8 \mathrm{~S}$ & 34.8 & 6.74 & $>20000$ & 4.155 & 716.3 & 108.6 & 3539 & 499 & 340.99 & 9.78 & 7275 & 68.1 & 12556.77 & 0.028 & 0.175 & 4.822 & 0.021 & 0.024 & 2233.87 \\
\hline $9 \mathrm{~S}$ & 12.5 & 7.58 & 45 & 10.46 & 7.58 & 1.44 & 4.54 & 0.64 & 32.02 & 4.78 & 5.1 & 7.89 & 63.99 & 0.420 & 0.001 & 0.005 & 0.013 & & 24.84 \\
\hline $10 \mathrm{~S}$ & 15 & 7.9 & 48 & 8.2 & 7.28 & 1.09 & 5.07 & 0.72 & 24.16 & 7.73 & 5.42 & 6.92 & 58.39 & 0.662 & 0.001 & 0.005 & 0.003 & 0.005 & 22.65 \\
\hline $11 \mathrm{~S}$ & 15.4 & 7.80 & 54 & 9.3 & 12.39 & 1.56 & 6.68 & 2.52 & 44.47 & 13.93 & 15.26 & 11.32 & 130.80 & 0.763 & 0.002 & 0.040 & 0.062 & 0.085 & 37.33 \\
\hline $12 \mathrm{~S}$ & 17.4 & 7.8 & 35 & 8.9 & 7.83 & 1.32 & 6.82 & 0.1 & 28.12 & 4.57 & 7.78 & 11.56 & 68.10 & 0.287 & 0.005 & 0.033 & 0.002 & 0.005 & 24.97 \\
\hline $13 \mathrm{~S}$ & 11.5 & 5.99 & 37 & 7.81 & 3.34 & 0.90 & 6.08 & 0.56 & 18.36 & 2.89 & 6.55 & 12.96 & 51.64 & 0.639 & 0.000 & 0.013 & 0.010 & 0.022 & 12.04 \\
\hline $14 \mathrm{~S}$ & 17 & 7.91 & & 8.12 & 4.29 & 1 & 5.16 & 0.3 & 21.35 & 2.82 & 6.35 & 9.38 & 50.65 & 0.079 & 0.002 & 0.036 & 0.005 & 0.016 & 14.82 \\
\hline $15 \mathrm{~S}$ & 15.3 & 7.03 & 123 & 9.2 & 40.38 & 4.94 & 8.55 & 0.49 & 133.47 & 12.07 & 8.09 & 11.22 & 219.21 & 1.565 & 0.002 & 0.019 & 0.005 & 0.027 & 121.07 \\
\hline $16 \mathrm{~S}$ & 11.2 & 8.03 & 170 & 10.61 & 25.73 & 5.63 & 30.47 & 1.64 & 84.06 & 17.66 & 60.79 & 10.41 & 236.39 & 0.912 & 0.000 & 0.013 & 0.007 & 0.071 & 87.35 \\
\hline $17 \mathrm{~S}$ & 13.8 & 6.97 & 88 & 9.68 & 9.59 & 2.06 & 7.61 & 1.1 & 30.38 & 8.67 & 11.83 & 17 & 88.24 & 1.366 & 0.001 & 0.011 & 0.023 & 0.046 & 32.40 \\
\hline $18 \mathrm{~S}$ & 21.1 & 7.41 & 130 & 6.44 & 4.99 & 2.07 & 18.05 & 0.76 & 26.66 & 13.34 & 19.07 & 40.92 & 125.86 & 0.095 & 0.001 & 0.025 & 0.065 & 0.076 & 20.96 \\
\hline $19 \mathrm{~S}$ & 17 & 7.6 & 54 & 9.2 & 17.03 & 3.78 & 14.46 & 1.84 & 62.46 & 15.59 & 16.86 & 13.58 & 145.60 & 0.585 & 0.000 & 0.022 & 0.023 & 0.043 & 58.04 \\
\hline $20 \mathrm{~S}$ & 17 & 7.8 & 130 & 7.2 & 104.95 & 26.72 & 38.94 & 0.088 & 372.10 & 72.87 & 51.51 & 17.54 & 684.72 & 8.484 & 0.001 & 0.005 & 0.001 & 0.005 & \\
\hline $21 \mathrm{~S}$ & 15.4 & 6.36 & 144 & 9.55 & 16.91 & 3.64 & 9.07 & 1.21 & 63.93 & 14.19 & 9.38 & 14.4 & 132.73 & 1.734 & 0.002 & 0.014 & 0.013 & 0.047 & 57.16 \\
\hline $22 \mathrm{~S}$ & 8.5 & 5.97 & 67 & 10.74 & 5.31 & 2.56 & 7.07 & 0.7 & 19.70 & 18.42 & 5.05 & 13.78 & 72.59 & 0.589 & 0.002 & 0.030 & 0.013 & 0.036 & 23.78 \\
\hline $23 \mathrm{~S}$ & 8.5 & 6 & 65 & 10.6 & 5.18 & 2.43 & 4.95 & 0.57 & 17.75 & 16 & 4.31 & 13.34 & 64.53 & 0.598 & 0.002 & 0.017 & 0.026 & 0.054 & 22.92 \\
\hline $24 \mathrm{~S}$ & 15.1 & 6.43 & 133 & 8.93 & 20.75 & 2.17 & 6.7 & 0.69 & 63.26 & 12.41 & 7.97 & 10.28 & 124.23 & 1.134 & 0.002 & 0.019 & 0.016 & 0.032 & 60.70 \\
\hline
\end{tabular}

Supplementary information

\begin{tabular}{|ccccccc|}
\hline Site Name & $\mathrm{N}^{\mathrm{o}}$ & Coordinates E & $\begin{array}{c}\text { Coordinates } \\
\mathrm{N}\end{array}$ & Date & Alt & Geology \\
& & & & & \\
\hline Ag.Sotiros & $1 \mathrm{~S}$ & 25.52323409 & 40.46704688 & $29-07-14$ & 276 & $\mathrm{~S}$ \\
Katsambas & $2 \mathrm{~S}$ & 25.52243815 & 40.47123301 & $27-08-13$ & 251 & $\mathrm{~S}$
\end{tabular}




\begin{tabular}{|ccccccc|} 
Ag. George & 3S & 25.52845261 & 40.47255004 & $30-11-12$ & 267 & $\mathrm{O}$ \\
Palaiopoli & 4S & 25.52768511 & 40.50277137 & $29-11-12$ & 11 & $\mathrm{~S}$ \\
Karuotes & $5 \mathrm{~S}$ & 25.54478551 & 40.50514457 & $30-11-12$ & 12 & $\mathrm{~S}$ \\
Therma (a) & $6 \mathrm{~S}$ & 25.60305438 & 40.49695082 & $29-11-12$ & 63 & $\mathrm{~S}$ \\
Therma (b) & $7 \mathrm{~S}$ & 25.60320536 & 40.49687701 & $29-11-12$ & 63 & $\mathrm{~S}$ \\
Therma (bath) & $8 \mathrm{~S}$ & 25.60180392 & 40.49744384 & $27-05-15$ & 55 & $\mathrm{~S}$ \\
Mounovrusa & $9 \mathrm{~S}$ & 25.5926857 & 40.48008894 & $12-05-14$ & 751 & $\mathrm{O}$ \\
Cold Water & $10 \mathrm{~S}$ & 25.58695621 & 40.4688338 & $17-08-13$ & 812 & $\mathrm{O}$ \\
Flower & $11 \mathrm{~S}$ & 25.59827529 & 40.45090792 & $19-08-14$ & 1176 & $\mathrm{G}$ \\
Karies & $12 \mathrm{~S}$ & 25.62188161 & 40.45223025 & $23-08-13$ & 701 & $\mathrm{G}$ \\
Itamos & $13 \mathrm{~S}$ & 25.62333611 & 40.45822208 & $05-05-14$ & 646 & $\mathrm{G}$ \\
Fonias (1) & $14 \mathrm{~S}$ & 25.62868045 & 40.46111195 & $19-08-14$ & 669 & $\mathrm{G}$ \\
Koufouklio & $15 \mathrm{~S}$ & 25.6321558 & 40.45798851 & $18-08-14$ & 894 & $\mathrm{G}$ \\
Kerasia & $16 \mathrm{~S}$ & 25.66876095 & 40.44310643 & $03-08-15$ & 272 & $\mathrm{O}$ \\
Ag. Thekla & $17 \mathrm{~S}$ & 25.62747012 & 40.41803919 & $31-07-15$ & 673 & $\mathrm{G}$ \\
Vatos (1) & $18 \mathrm{~S}$ & 25.61004114 & 40.40903519 & $31-07-15$ & 474 & $\mathrm{G}$ \\
Vatos (2) & $19 \mathrm{~S}$ & 25.60129311 & 40.39527803 & $25-08-13$ & 16 & $\mathrm{~S}$ \\
Dafnes & $20 \mathrm{~S}$ & 25.53184802 & 40.42225837 & $27-08-13$ & 104 & $\mathrm{~S}$ \\
PanoPanagia & $21 \mathrm{~S}$ & 25.54478138 & 40.43370395 & $01-08-14$ & 343 & $\mathrm{~S}$ \\
Sfendami (left) & $22 \mathrm{~S}$ & 25.56488165 & 40.44922963 & $27-07-14$ & 1061 & $\mathrm{BU}$ \\
Sfendami (right) & $23 \mathrm{~S}$ & 25.56544514 & 40.44925783 & $27-07-14$ & 1068 & $\mathrm{BU}$ \\
Panagia Mantalo & $24 \mathrm{~S}$ & 25.54528572 & 40.44833494 & $01-08-14$ & 465 & $\mathrm{O}$ \\
\hline & & & & & & \\
\hline
\end{tabular}




\section{Appendix III}

HYDROCHEMICAL PROPERTIES OF STREAMS EXAMINED BY HCMR (AVERAGE VALUES FROM SEVERAL SAMPLING CAMPAIGNS)

\begin{tabular}{|c|c|c|c|c|c|c|c|c|c|c|c|c|c|c|c|c|c|c|c|c|c|c|}
\hline $\mathrm{A} / \mathrm{A}$ & NS & & $\mathrm{T}$ & $\mathrm{pH}$ & & & & & & & & $\mathrm{Cl}$ & & TDS & & DO & $\begin{array}{c}\mathrm{N}- \\
\mathrm{NO} 3\end{array}$ & $\begin{array}{c}\mathrm{N}- \\
\mathrm{NO} 2\end{array}$ & $\begin{array}{c}\mathrm{N}- \\
\mathrm{NH} 4\end{array}$ & $\begin{array}{c}\text { P- } \\
\text { PO4 }\end{array}$ & $\begin{array}{c}\text { Total } \\
\mathrm{P}\end{array}$ & $\begin{array}{l}\text { Physico- } \\
\text { chemical }\end{array}$ \\
\hline & & $(\mathrm{m} 3 / \mathrm{s})$ & $(\mathrm{oC})$ & & $(\mu \mathrm{s} / \mathrm{cm})$ & $(\mathrm{mg} / \mathrm{l})$ & $(\mathrm{mg} / \mathrm{l})$ & $(\mathrm{mg} / \mathrm{l})$ & $(\mathrm{mg} / \mathrm{l})$ & $(\mathrm{meq} / \mathrm{l})$ & $(\mathrm{mg} / \mathrm{l})$ & $(\mathrm{mg} / \mathrm{l})$ & $(\mathrm{mg} / \mathrm{l})$ & $(\mathrm{mg} / \mathrm{l})$ & $(\mathrm{mg} / \mathrm{lCaCO} 3)$ & $\mathrm{mg} / \mathrm{l}$ & $\mathrm{mg} / \mathrm{l}$ & $\mathrm{mg} / \mathrm{l}$ & $\mathrm{mg} / \mathrm{l}$ & $\mathrm{mg} / \mathrm{l}$ & $\mathrm{mg} / \mathrm{l}$ & Quality \\
\hline 1.1 & 1 & 0.030 & 17 & 7.26 & 188 & 33.77 & 4.7 & 7.63 & 0.41 & 1.847 & 12.58 & 15.3 & 11.3 & 198.4 & 103.59 & 9.50 & 1.409 & 0.001 & 0.012 & 0.016 & 0.039 & $\mathrm{H}$ \\
\hline 1.2 & 3 & 0.042 & 19.7 & 7.93 & 324 & 50.38 & 6.85 & 14.88 & 2.62 & 2.68 & 15.13 & 16.31 & 12.6 & 282.3 & 153.87 & 9.06 & 2.660 & 0.018 & 0.033 & 0.276 & 0.354 & $\mathrm{M}$ \\
\hline 1.3 & 1 & 0.032 & 24.8 & 8.05 & 331 & 52.05 & 7.19 & 13.4 & 2.33 & 2.993 & 15.49 & 12.41 & 12.4 & 297.9 & 159.44 & 8.77 & 0.858 & 0.002 & 0.026 & 0.166 & 0.172 & $\mathrm{G}$ \\
\hline 6.1 & 2 & 0.145 & 14.5 & 7.80 & 67 & 14.29 & 3.29 & 6.42 & 0.67 & 0.97 & 7.74 & 6.79 & 11.7 & 110.3 & 49.15 & 10.05 & 0.403 & 0.001 & 0.016 & 0.005 & 0.010 & $\mathrm{H}$ \\
\hline 7.1 & 2 & 0.051 & 16.7 & 7.86 & 149 & 20.81 & 4.25 & 7.71 & 0.55 & 1.28 & 8.56 & 8.45 & 14.6 & 142.9 & 69.40 & 9.90 & 0.187 & 0.002 & 0.017 & 0.011 & 0.022 & $\mathrm{H}$ \\
\hline 8.1 & 2 & 0.109 & 18.1 & 7.25 & 49 & 16.77 & 4.03 & 8.83 & 0.52 & 1.11 & 7.54 & 9.45 & 13.4 & 128.2 & 58.38 & 9.61 & 0.281 & 0.002 & 0.038 & 0.008 & 0.014 & $\mathrm{H}$ \\
\hline 9.1 & 2 & 0.082 & 16.6 & 7.4 & 53 & 6.9 & 1.2 & 4.7 & 0.8 & 0.4 & 6.7 & 5.1 & 6.8 & 58.2 & 22.3 & 10.40 & 0.567 & 0.001 & 0.018 & 0.011 & 0.025 & $\mathrm{H}$ \\
\hline 9.2 & 2 & 0.110 & 16.1 & 7.4 & 46 & 6.4 & 1.1 & 4.9 & 0.8 & 0.4 & 5.9 & 5.7 & 6.3 & 54.3 & 20.4 & 10.32 & 0.545 & 0.001 & 0.020 & 0.015 & 0.039 & $\mathrm{H}$ \\
\hline 9.3 & 9 & 0.072 & 20.2 & 7.4 & 112 & 14.2 & 2.7 & 7.3 & 0.3 & 0.9 & 10.1 & 9.4 & 9.3 & 107.5 & 41.0 & 9.52 & 0.498 & 0.001 & 0.015 & 0.030 & 0.070 & $\mathrm{H}$ \\
\hline 9.4 & 1 & 0.010 & 16.5 & 8.1 & 92 & & & & & & & & & & & 9.79 & 0.064 & $<\mathrm{LOQ}$ & 0.011 & 0.005 & & $\mathrm{H}$ \\
\hline 9.5 & 1 & 0.021 & 19.9 & 6.92 & 109 & 15.47 & 3.19 & 7.35 & 0.72 & 1.03 & 13.52 & 10.54 & 11.5 & 125.2 & 51.72 & 8.85 & 0.244 & 0.001 & 0.022 & 0.013 & 0.038 & $\mathrm{H}$ \\
\hline 10.1 & 2 & 0.038 & 17.1 & 7.57 & 76 & 10.61 & 1.41 & 6.65 & 0.71 & 0.64 & 5.65 & 10.05 & 12.4 & 86.4 & 32.24 & 10.05 & 0.264 & 0.001 & 0.012 & 0.009 & 0.020 & $\mathrm{H}$ \\
\hline 11.1 & 1 & 0.083 & 19.8 & 6.41 & 55 & 5.85 & 1.1 & 6.89 & 0.1 & 0.447 & 3.95 & 9.21 & 14.2 & 68.5 & 19.12 & 9.22 & 0.111 & 0.001 & 0.124 & 0.039 & 0.087 & G \\
\hline 11.2 & 1 & 0.061 & 26.1 & 6.81 & 104 & 13.31 & 2.06 & 8.12 & 0.61 & 0.949 & 4.74 & 9.21 & 16.2 & 112.1 & 41.68 & 7.65 & 0.278 & 0.002 & 0.027 & 0.005 & 0.032 & $\mathrm{H}$ \\
\hline 12.1 & 2 & 0.385 & 14.5 & 7.5 & 49 & 6.3 & 1.0 & 5.4 & 0.7 & 0.4 & 4.8 & 5.2 & 6.7 & 56.9 & 19.7 & 10.30 & 0.570 & 0.001 & 0.030 & 0.005 & 0.017 & $\mathrm{H}$ \\
\hline 12.2 & 5 & 0.199 & 13.7 & 7.2 & 159 & 7.1 & 1.3 & 6.5 & 0.8 & 0.5 & 4.8 & 7.1 & 8.1 & 64.9 & 22.9 & 10.68 & 0.473 & 0.001 & 0.026 & 0.007 & 0.017 & $\mathrm{H}$ \\
\hline 12.3 & 9 & 0.194 & 14.8 & 7.8 & 68 & 6.9 & 1.2 & 6.3 & 1.1 & 0.6 & 6.0 & 7.5 & 9.1 & 76.5 & 24.7 & 9.77 & 0.442 & 0.002 & 0.060 & 0.046 & 0.099 & $\mathrm{H}$ \\
\hline 15.1 & 3 & 0.206 & 15.8 & 8.05 & 97 & 16.96 & 2.38 & 8.21 & 0.72 & 0.79 & 13.03 & 13.18 & 9.8 & 112.3 & 52.10 & 9.71 & 0.823 & 0.001 & 0.023 & 0.009 & 0.018 & $\mathrm{H}$ \\
\hline 15.2 & 2 & 0.240 & 19.3 & 7.54 & 126 & 16.34 & 2.74 & 9.19 & 0.84 & 0.90 & 13.83 & 11.34 & 11.4 & 120.8 & 52.03 & 10.19 & 0.456 & 0.001 & 0.020 & 0.015 & 0.022 & $\mathrm{H}$ \\
\hline
\end{tabular}




\begin{tabular}{|c|c|c|c|c|c|c|c|c|c|c|c|c|c|c|c|c|c|c|c|c|c|c|}
\hline 17.1 & 1 & 0.038 & 22.3 & 7.14 & 252 & 48.67 & 5.27 & 11.09 & 0.07 & 2.590 & 13.96 & 17.11 & 12.88 & 267.1 & 143.11 & 7.77 & 0.151 & $<\mathrm{LOQ}$ & 0.041 & 0.005 & 0.005 & $\mathrm{H}$ \\
\hline 18.1 & 1 & & 24.2 & 7.17 & 82 & 7.96 & 1.28 & 6.84 & 0.10 & 0.35 & 7.15 & 11.57 & 12.1 & 68.5 & 25.13 & 8.16 & 0.650 & 0.002 & 0.057 & 0.004 & 0.031 & $\mathrm{G}$ \\
\hline 18.2 & 2 & 0.315 & 19.1 & 7.52 & 63 & 10.12 & 1.54 & 7.99 & 1.01 & 0.56 & 11.14 & 10.06 & 11.1 & 87.2 & 31.58 & 10.25 & 0.689 & 0.002 & 0.029 & 0.014 & 0.029 & $\mathrm{H}$ \\
\hline 19.1 & 1 & & 20.3 & 7.03 & 101 & 10.19 & 4.81 & 34.68 & 1.69 & 0.556 & 16.19 & 62.7 & 18.4 & 182.6 & 45.21 & 8.12 & 0.720 & 0.001 & 0.025 & 0.012 & 0.088 & $\mathrm{G}$ \\
\hline 20.1 & 1 & 0.307 & 21.1 & 6.84 & 106 & 14.08 & 2.76 & 11.07 & 1.15 & 0.76 & 15.61 & 14.00 & 17.0 & 121.9 & 46.48 & 7.39 & 0.210 & 0.001 & 0.013 & 0.023 & 0.035 & $\mathrm{H}$ \\
\hline 20.2 & 2 & 0.364 & 17.6 & 7.69 & 77 & 11.17 & 2.27 & 10.62 & 1.12 & 0.76 & 10.91 & 11.38 & 9.7 & 103.6 & 37.19 & 10.16 & 0.351 & 0.001 & 0.014 & 0.019 & 0.026 & $\mathrm{H}$ \\
\hline 21.1 & 1 & 0.040 & 20.4 & 7.33 & 379 & 57.98 & 14.68 & 20.28 & 0.27 & 3.415 & 25.99 & 24.97 & 19.5 & 372.1 & 205.04 & 8.86 & 4.602 & 0.004 & 0.009 & 0.059 & 0.082 & G \\
\hline 21.2 & 3 & 0.785 & 18.7 & 7.80 & 325 & 61.27 & 13.05 & 22.26 & 1.67 & 3.49 & 24.82 & 24.88 & 17.1 & 378.2 & 206.56 & 9.84 & 2.624 & 0.002 & 0.036 & 0.045 & 0.054 & G \\
\hline 21.3 & 3 & 0.021 & 16.7 & 7.57 & 271 & 66.60 & 15.66 & 30.08 & 3.12 & 4.13 & 28.12 & 35.02 & 18.7 & 449.5 & 230.57 & 8.49 & 2.208 & 0.008 & 0.062 & 0.183 & 0.191 & M \\
\hline 22.1 & 4 & 0.176 & 15.1 & 7.97 & 204 & 33.22 & 3.35 & 7.28 & 0.86 & 1.68 & 11.46 & 7.98 & 9.7 & 176.4 & 96.65 & 10.36 & 0.479 & 0.002 & 0.026 & 0.007 & 0.062 & $\mathrm{H}$ \\
\hline 22.2 & 1 & 0.045 & 19.1 & 8.3 & 239 & & & & & & & & & & & 10.04 & 0.143 & $<\mathrm{LOQ}$ & 0.008 & 0.003 & & $\mathrm{H}$ \\
\hline 23.1 & 2 & 0.014 & 16.9 & 8.07 & 313 & 51.42 & 7.30 & 13.39 & 0.77 & 2.79 & 13.20 & 16.51 & 13.2 & 285.7 & 158.29 & 10.04 & 0.848 & 0.001 & 0.036 & 0.024 & 0.030 & $\mathrm{H}$ \\
\hline 23.2 & 1 & 0.016 & 23.7 & 7.42 & 390 & 66.99 & 11.01 & 16.83 & 0.30 & 3.66 & 18.97 & 36.84 & 17.7 & 391.9 & 212.43 & 8.30 & 1.786 & 0.002 & 0.014 & 0.069 & 0.113 & G \\
\hline
\end{tabular}

\section{Supplementary information}

\begin{tabular}{|c|c|c|c|c|c|c|c|c|c|c|c|c|c|c|}
\hline River name & Site name & $\begin{array}{c}\text { Code } \\
\text { on } \\
\text { map }\end{array}$ & Coordinates & Coordinates & Ophiolites. & Granites & Sediments & Bedrock & Boulder & Cobble & Gravel & $\begin{array}{l}\text { Coarse- } \\
\text { Sand }\end{array}$ & Sand & Clay \\
\hline & & & E & $\mathrm{N}$ & $(\%)$ & $(\%)$ & (\%) & $(\%)$ & (\%) & $(\%)$ & $(\%)$ & $(\%)$ & $(\%)$ & $(\%)$ \\
\hline Katsambas & Kastro & 1.1 & 25.527288 & 40.473208 & 99.4 & 0 & 0.6 & 0 & 20 & 40 & 10 & 20 & 10 & 0 \\
\hline Katsambas & Chora & 1.2 & 25.518756 & 40.480732 & 43.6 & 0 & 56.4 & 0 & 20 & 40 & 10 & 0 & 0 & 30 \\
\hline Katsambas & $\begin{array}{c}\text { Chora } \\
\text { Downstream }\end{array}$ & 1.3 & 25.508854 & 40.486996 & 44.3 & 0 & 55.7 & 0 & 10 & 10 & 30 & 0 & 20 & 30 \\
\hline
\end{tabular}




\begin{tabular}{|c|c|c|c|c|c|c|c|c|c|c|c|c|c|}
\hline Arapis & AnoKaruotes & 6.1 & 25.581744 & 40.489643 & 99.7 & 0 & 0.3 & 10 & 40 & 30 & 10 & 10 & 0 \\
\hline Thermiotis & Therma & 7.1 & 25.602799 & 40.493728 & 92.3 & 0 & 7.7 & 0 & 0 & 70 & 10 & 10 & 10 \\
\hline Tsivdogiannis & Nekrotafeio & 8.1 & 25.609368 & 40.496399 & 86.3 & 0 & 13.7 & 5 & 5 & 60 & 20 & 10 & 0 \\
\hline Platia & Alonitious & 9.1 & 25.598739 & 40.470970 & 84.7 & 10 & 5.3 & 0 & 10 & 60 & 20 & 10 & 0 \\
\hline Platia & Prinos & 9.2 & 25.603849 & 40.474733 & 49.5 & 48.8 & 1.7 & 0 & 10 & 60 & 20 & 10 & 0 \\
\hline Platia & Gria Vathra1 & 9.3 & 25.611303 & 40.492521 & 59.8 & 31.7 & 8.5 & 0 & 80 & 10 & 0 & 5 & 5 \\
\hline Platia & Gria Vathra2 & 9.4 & 25.614717 & 40.496942 & 56.2 & 29.8 & 14 & 0 & 70 & 20 & 0 & 5 & 5 \\
\hline Platia & $\begin{array}{l}\text { GriaVathra } \\
\text { DW }\end{array}$ & 9.5 & 25.615808 & 40.500029 & 54.3 & 29.7 & 16 & 0 & 70 & 20 & 5 & 5 & 0 \\
\hline Kardelis & Grigorakis & 10.1 & 25.619182 & 40.486021 & 14.4 & 80.1 & 5.5 & 0 & 10 & 30 & 20 & 10 & 30 \\
\hline Varades & Varades 1 & 11.1 & 25.631055 & 40.492499 & 15.4 & 80.7 & 3.9 & 0 & 70 & 15 & 10 & 0 & 5 \\
\hline Varades & Varades 2 & 11.2 & 25.629748 & 40.490524 & 14.8 & 54.6 & 30.6 & 0 & 5 & 30 & 25 & 0 & 20 \\
\hline Fonias & Fonias Springs & 12.1 & 25.620474 & 40.453815 & 1.8 & 98.2 & 0 & 0 & 30 & 40 & 20 & 0 & 10 \\
\hline Fonias & Fonias 1 & 12.2 & 25.645155 & 40.478003 & 9.5 & 89.3 & 1.2 & 0 & 5 & 70 & 0 & 10 & 15 \\
\hline Fonias & Fonias 2 & 12.3 & 25.652187 & 40.489934 & 8.8 & 82.9 & 8.3 & 0 & 70 & 10 & 0 & 5 & 15 \\
\hline Agkistros & Agistros 1 & 15.1 & 25.652361 & 40.450152 & 45 & 55 & 0 & 0 & 5 & 60 & 30 & 5 & 0 \\
\hline Agkistros & Agistros 2 & 15.2 & 25.667252 & 40.456879 & 45.6 & 43.1 & 11.3 & 0 & 0 & 60 & 30 & 5 & 5 \\
\hline Lagkadiotis & Lagkadiotis 1 & 17.1 & 25.683949 & 40.438833 & 72.4 & 0 & 25.6 & 0 & 0 & 0 & 80 & 10 & 10 \\
\hline Giali & Giali 1 & 18.1 & 25.635937 & 40.423535 & 3.9 & 96.1 & 0 & 0 & 20 & 40 & 20 & 0 & 20 \\
\hline Giali & Giali 2 & 18.2 & 25.647496 & 40.411119 & 24.3 & 75.7 & 0 & 0 & 30 & 40 & 20 & 0 & 0 \\
\hline Kremasto & Kremasto & 19.1 & 25.624175 & 40.415407 & 0 & 100 & 0 & 75 & 10 & 5 & 0 & 5 & 0 \\
\hline Vatos & Karagiannakis & 20.1 & 25.581668 & 40.421995 & 20.7 & 79.3 & 0.01 & 0 & 70 & 25 & 5 & 0 & 0 \\
\hline Vatos & Vatos & 20.2 & 25.595528 & 40.404196 & 7.3 & 91.8 & 0.9 & 0 & 30 & 50 & 10 & 0 & 10 \\
\hline Lakoma & Kasteli & 21.1 & 25.539632 & 40.432352 & 48.9 & 0 & 51.1 & 0 & 30 & 50 & 15 & 5 & 0 \\
\hline Lakoma & Lakoma 1 & 21.2 & 25.533429 & 40.427271 & 43.6 & 0 & 56.4 & 0 & 5 & 30 & 45 & 10 & 10 \\
\hline
\end{tabular}




\begin{tabular}{|c|c|c|c|c|c|c|c|c|c|c|c|c|c|}
\hline Lakoma & Lakoma 2 & 21.3 & 25.528661 & 40.423500 & 32 & 0 & 68 & 0 & 5 & 50 & 25 & 10 & 10 \\
\hline Xiropotamos & Xiropotamos 1 & 22.1 & 25.527042 & 40.446744 & 71 & 2.1 & 26.9 & 0 & 50 & 30 & 15 & 3 & 2 \\
\hline Xiropotamos & Xiropotamos 2 & 22.2 & 25.511741 & 40.426627 & 64.6 & 1.8 & 33.6 & 0 & 20 & 60 & 0 & 18 & 2 \\
\hline Polupoudi & Alonia & 23.1 & 25.521237 & 40.465115 & 60.7 & 0 & 39.3 & 0 & 30 & 50 & 10 & 10 & 0 \\
\hline Polupoudi & Polupoudi DW & 23.2 & 25.502996 & 40.457430 & 45.4 & 0 & 54.6 & 0 & 35 & 55 & 5 & 0 & 5 \\
\hline
\end{tabular}

